\title{
Areas of Endemism of Selected Seed Plants in Southcentral and Southwestern USA
}

\author{
Anna Saghatelyan ${ }^{1}$ \\ ${ }^{1}$ McMurry University
}

July 8,2021

\begin{abstract}
Areas of endemism (AEs) are fundamental entities of analysis in biogeography and a key step for biogeographical regionalization. Even though many studies have contributed to the biogeographical knowledge of southern USA flora, no endemicity analysis (EA) has been conducted that would include a large number of native seed plant species from different families. A new analysis of plant spatial patterns is important as a first step for a future updated floristic regionalization of North America North of Mexico. It has become easier to accomplish owing to the increased availability of large-scale digitized distributional data and statistical methods of biogeographic analysis. Here we identify the AEs in SC/SW USA using digitized plant specimen data available from IDigBio. We built a database with 81,851-specimen point records of 400 selected mostly angiosperm species and applied the NDM/VNDM method of endemicity analysis. We then compare the established 26 AEs in the area of study with the floristic provinces in two comparatively recent regionalization systems of USA. To understand the spatial patterns, we also pay attention to the information on relationships of the endemic species found in phylogenetic literature.
\end{abstract}
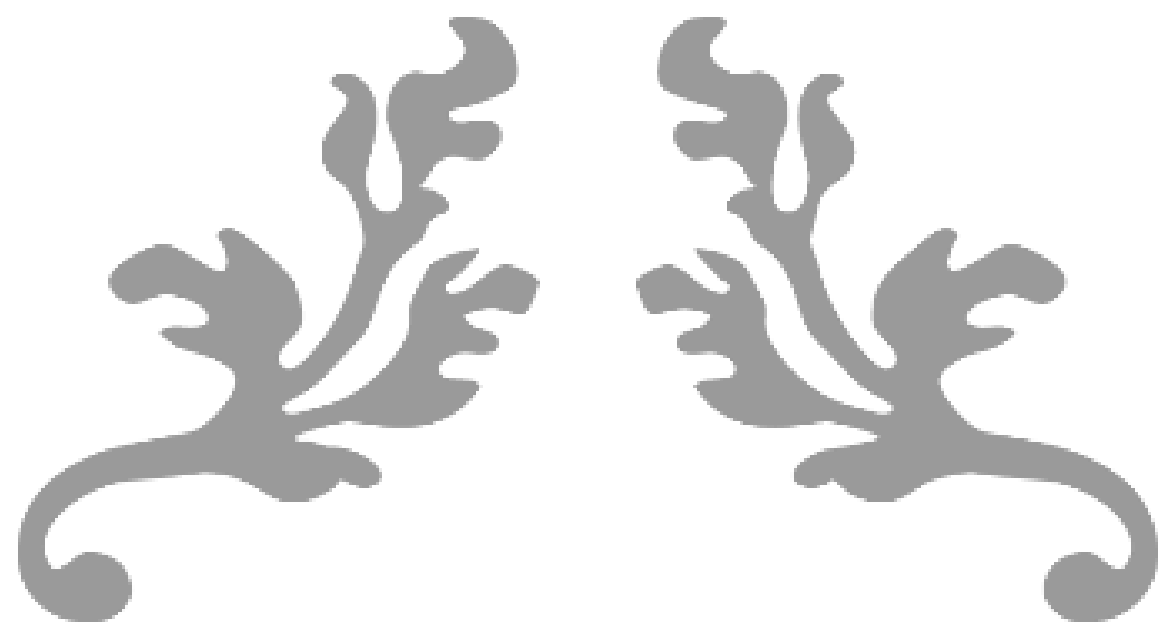


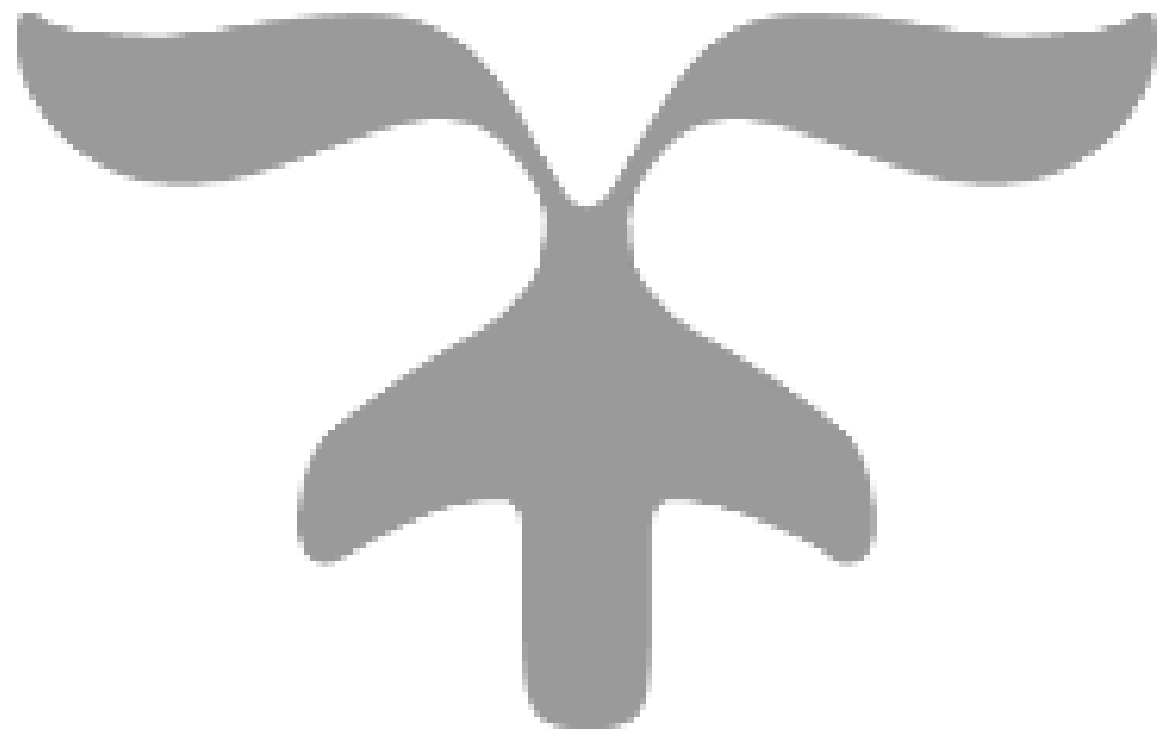

\section{Introduction}

By defining areas of relatively homogeneous species composition, biogeographical frameworks provide spatial units of analysis that are useful in macroecological, evolutionary and systematic studies of the processes, which shaped or maintain species distributions (Morrone, 2018). The search for congruent species distributions ultimately defines choria, which are, according to Takhtajan (1978), units of different ranks in a hierarchical floristic regionalization system. They are distinct from the units of ecological regionalization (ecoregions), which define biomes. The inclusion of widespread species in the biogeographic analysis resolves the patterns of biomes, rather than historical areas, as was recently shown for Australia (Murphy et al., 2019). Conversely, regionalization systems based on endemic species (e.g., by Cronquist, 1982; Takhtajan, 1986; Rzedowski, 1978; Morrone, 2014; Morrone et al., 2017), rather than biomes, resolve historical areas.

The search for floristic patterns starts with finding areas of endemism (AE), which are fundamental entities of analysis in biogeography, and this is a key step for biogeographical regionalization (Morrone, 1994; Escalante, 2009; Linder, 2001; Mercado Gomez \& Escalante, 2018; Liria et al., 2020). An adequate regionalization reflects the history of the assembly of a flora. Immigrant species/ancestors to local radiations enter a flora from different directions and at different times. Early studies (Popov, 1963, 1983; Kamelin, 1973, 1998; Raven and Axelrod, 1995) provided insight into history of a complex flora by subdividing a flora into species complexes of different ages and origins. More recently, analysis of cenocrons (Morrone, 2009, 2010; CorralRosas \& Morrone, 2017; Halffter \& Morrone, 2017; and Ferro et al., 2017), based on advances in phylogenetic systematics and historical biogeography, resulted in time slicing of the biota into sets of taxa that share the same biogeographic history.

The history and connections of the flora of southcentral/southwestern (SC/SW) North America have long been a subject of research (Axelrod, 1958, 1975; Raven \& Axelrod, 1995; Rzedowski, 1993; Sosa \& De-Nova, 2012; Graham, 2018; Sosa et al., 2018; Sosa et al., 2020; Baldwin, 2014; Baldwin et al., 2017; VasquezCruz \& Sosa, 2019; Mishler et al., 2020). The widely accepted major biotic boundary in North America, Nearctic/Neotropical, is defined as the Mexican transition zone (Morrone, 2010, 2015, 2018; Halffter \& Morrone, 2017). A second major boundary is east to west boundary (Katinas et al., 2004; Escalante et al., 2013, Gamez et al., 2016; Mishler et al., 2020). In southern USA, it passes through Texas (Saghatelyan 2009, 2015, 2017), where it separates almost adjacent floras of Big Bend National Park (BB) and the Edwards Plateau (EP) (Map 1, Supplemental Information 1). In the floristic regionalization system of North America by Takhtajan (1987), BB falls in the Madrean region (MR) while EP falls in the Atlantic region (ER) of the Madrean and Boreal subkingdoms respectively. McLaughlin (2007) regionalization system identifies the 
$\mathrm{MR}$ as the Southwestern region (SW), including the North American Prairies province. The latter province is a part of the ER in the Takhtajan scheme. Disagreements in some aspects of these two more recent floristic systems necessitate a new analysis of geographic patterns of plants with more comprehensive species distribution data across SC/SW USA. This has become easier owing to the increased availability of largescale digitized distributional data and novel statistical methods of biogeographic analysis. Many authors search biogeographic units using clustering algorithms (McLaughlin, 2007; Linder et al., 2012; MunguioLina et al., 2016; Ye et al., 2019; Wang et al., 2019), e.g., the McLaughlin system resulted from a principal component analysis applied to a large set of local floras. The Takhtajan system used thresholds of endemism at successively finer taxonomic ranks to distinguish choria at different ranks.

A widely used method of endemicity analysis searches for areas of endemism (AE)s, which are patterns of co-occurrence in the geographical distribution of endemic taxa defined by the non-random congruence of occurrences between different taxa (Szumik et al., 2002). The first explicitly defined and detailed methods for finding AEs were proposed by Morrone (1994, 2009), with an AE defined as a group of geographic units that share at least two species. The studies on endemicity analyses in the Americas mostly use animals rather than plants and with the abundance of digitized distribution data for plants, it is feasible to use them for finding AEs.

Bertelli et al. (2017) argue that studies that have sought to discover patterns of endemism generally have not been sufficiently fine grained spatially and have not undertaken the 'discovery' process in a manner that minimizes assumptions and biases. To understand the biogeographic patterns in SC/SW USA, we first aim to identify the "unbiased" AEs using digitized plant specimen data available from IDigBio. We built a database with 81,851-specimen point records of 400 selected vascular plant species and applied the NDM/VNDM method of endemicity analysis (Szumik et al., 2002; Szumik \& Goloboff, 2004) on different resolution scales. We then compare the established AEs with the floristic provinces/subprovinces and search for the relatives of the species that are endemic to these AEs in phylogenetic literature.

\section{Materials and Methods}

\subsection{Study Area}

The study area was determined to be from $-125^{\circ}$ to $-75 \mathrm{deg}$ longitude and $20 \mathrm{deg}$ to $45 \mathrm{deg}$ latitude to accommodate the global ranges of most species included in the database. The native floras of three regions, BB, EP, and South Texas Plains (S TX) in southern Texas (Map 1, Appendix 1) were the sources of the majority of species in the database. Additional species were selected from the floras of northern Sonora and Mohave Deserts, the Great Basin, and the southern California Floristic province (CFP).

The Big Bend in West Texas is distinct from the surrounding areas because of its numerous mountain systems and low arid basins with elevations ranging from 1000 to $7835 \mathrm{ft}$ (Powell, 1998; Powell \& Worthington, 2018). It is part of the Chihuahuan subprovince. The Edwards Plateau in south-central Texas, with elevations ranging from 450 to $3000 \mathrm{ft}$., is situated in the southern Prairies province. Its climax vegetation (before European settlement) was an open temperate grassland, with shrubs and low trees along rocky slopes. South Texas Plains, located to the south of the Edwards Plateau, support extensive subtropical dryland thorn scrub and mesquite-grassland vegetation (Correll \& Johnston 1970). This mostly sandy area in the Rio Grande Plain accommodates representatives of genera and even families not found indigenous elsewhere in North America North of Mexico (Thorne, 1993). Sixty-six woody species reach their northern limit of distribution in S TX (Lonard et al., 1991).

\subsection{Sources of Data}

We compiled the database with 81,851records of 400 species in 174 genera and 61 families of angiosperms, and 2 genera in 2 families of gymnosperms. More than half of the species were selected, using the classification of geoelements (species with congruent distributions) from the checklists of BB, EP, and S TX (Saghatelyan, 2009, 2015, 2017) to represent the different floristic regions and provinces which intersect in Texas. Also included are species of the western parts of the Madrean region in the USA from the floras of southern 
Arizona, New Mexico, and California (SENet Portal: http://swbiodiversity.org/seinet/; The Jepson Flora Project; https://ucjeps.berkeley.edu/jepsonflora/). To sample the central Rocky Mountains/Great Basin area we included species from Bear River flora, Utah (L. Shultz, Utah State University, personal communication). Widespread species with ranges covering most of the study area were avoided, while the species well represented in the dry areas of southern USA were included. The members of extensively studied families of eudicots with molecular phylogenies of their representative genera published in recent years were preferentially included in the database. Seven such families comprise 254 species ( $63.5 \%$ of all the species): Asteraceae (111 sp.), Fabaceae (43 sp.), Apocynaceae (28 sp.), Hydrophyllaceae (23 sp.), Boraginaceae (19 sp.), Cactaceae (19 sp.), and Nyctaginaceae (11 sp.).

The species of the sonoran, madrean, madro-tethyan, and tropical/subtropical genera were selected over species of widespread temperate genera. The species of temperate genera connected with the Old World via Bering Land Bridge (BLB), e.g. Astragalus L., are mostly from the temperate Bear River flora checklist. Digitized herbarium specimen data were downloaded from the Integrated Digitized Biocollections (http://www.idigbio.org/portal), last accessed January -April 2020. The nomenclature was checked with International Plant Name Index (IPNI). During the cleaning we eliminated duplicates, records on university campuses or botanical gardens, erroneous records, such as "0" or "NA" values for latitude and longitude; occasional points in southern or eastern hemisphere; in cases with ample occurrence points per species, older than 1950 records were purged. The maps were contrasted with those documented by the Biota of North America Project (BONAP; https://bonap.org, accessed April-May 2020), online databases (e.g., EOL: https://eol.org/), and literature (Turner at al., 2003). The final database included 81, 851 specimen point records of 400 species with $7-800$ points per species. The species list is in the Appendix 3.

\subsection{Endemicity Analysis}

We searched for AEs using the NDM/VNDM v.2.7 program $(2004,2016)$, which applies the method proposed by Szumik et al. (2002) and Szumik \& Goloboff (2004). As input data, NDM uses a list of species that includes georeferenced locations for each specimen, automatically transformed into a presence/absence matrix in cells of a user-defined grid. The method searches for areas (sets of cells) that are congruent with the distribution of as many species as possible. It identifies an $\mathrm{AE}$ as the congruent distribution of two or more species. Based on an optimality criterion, NDM evaluates a candidate area (an area set) by assigning a score to each species depending on how well the species fits the area, with absence in parts of the area and presence in cells outside the area being penalized.

All the areas receive an endemicity score (E), which is the sum of the scores of the supporting species. The $\mathrm{E}$ value improves with both the number of species concordant with the area and the degree of concordance between the area and those species (Aagesen et al., 2013).

Preliminary analyses were performed with varying grid sizes to explore different analytical options and to increase the chances of finding different areas. Additionally, the areas that survive changes in grid size can be considered to be more strongly supported by the data (Elias \& Aagesen, 2019).

We analyzed the dataset with 81,851 points of 400 species with three different cell sizes to explore the distribution patterns at different scales and the robustness of the resulting areas to changes in grid size. Grids at cell sizes of $2.5 \mathrm{deg}$ latitude x $1.5 \mathrm{deg}$ longitude, $3 \mathrm{deg}$ latitude x $1.5 \mathrm{deg}$ longitude, and $3 \mathrm{deg}$ latitude x 2.5deg longitude; $\mathrm{R}$ fill: $5 \times$ x 5 ; and $\mathrm{R}$ to assume $10 \times 10$ were used.

A separate NDM/VNDM analysis was carried out with a subset of the database comprised of 259 more southern species (from the floras of southern Texas, Arizona, and New Mexico). This smaller database comprising 49, 290 point occurrences was analyzed with grids: $1.8 \mathrm{deg} \times 1.8 \mathrm{deg}, 2.7 \mathrm{deg}$ latitude $\mathrm{x} 2.4 \mathrm{deg}$ longitude, $2.6 \mathrm{deg} \times 2.6 \mathrm{deg}, 4.5 \mathrm{deg} \times 4.5 \mathrm{deg}$, and $5 \mathrm{deg} \times 5 \mathrm{deg}$.

Final endemicity analyses were performed using NDM ver. 3.1 (Goloboff, 2016), saving all sets with scores higher than or equal to 2.0 with two or more defining species. The search was run 100 times, and overlapping subsets were retained if $98 \%$ of their defining species were unique. Each search was executed using edge 
proportions. From the sets obtained with the larger database at cell sizes $2.5 \mathrm{deg} \times 1.5 \mathrm{deg}$ and $3 \mathrm{deg} \times \mathrm{x} 1.5 \mathrm{deg}$ we chose the endemic species with a minimum score 0.68 , and for the analysis with $3 \mathrm{deg} \times \mathrm{x} 2.5 \mathrm{deg}$ cells we chose the species with the minimum score 0.75 and calculated the consensus areas (CAs) at $40 \%$ similarity. We used the loose rule, which combines all area sets that share a user-defined percentage of their defining species with at least one other area set in the consensus (Aagesen et al., 2013). From the sets obtained with the smaller database, we chose only the endemic species with a minimum score of 0.7 and calculated the consensus areas (CAs) at 50\% similarity for 1.8deg cells; $70 \%$ and $40 \%$ similarity for medium and larger (4.5deg x $4.5 \mathrm{deg}$, and $5 \mathrm{deg} \times 5 \mathrm{deg}$ ) cell sizes respectively.

The results were examined using VNDM. The CAs of all grid sizes were converted into shapefiles (.shp) and mapped with QGIS version 3.6.3 (http://qgis.osgeo.org). Several CAs produced by the analyses with varying cell sizes had a similar outline and only one or two endemic species differences. We kept only one such CA as an AE (Table I; Table S1, Appendix 2) and named the AEs after known floristic provinces or using geographic terms. We compared the outlines of the AEs with the units in the floristic regionalization of Takhtajan (1987) and McLaughlin (2007).

\section{Results}

\subsection{Endemicity Analysis}

The results of endemicity analysis of the database with 400 species are summarized in Fig. 1, Table 1, and Table S1, Appendix 2. NDM analysis with grids 2.5deg latitude x 1.5deg longitude produced 19 CAs from 80 sets with the endemicity scores from 1.21 (supported by 1 species) to 23.57 (supported by 61 species). Two more CAs had high scores: 17.36 (supported by 33 species) and 12.75 (supported by 20 species.)

The analysis with grids $3 \mathrm{deg}$ latitude $\mathrm{x} 1.5 \mathrm{deg}$ longitude produced $43 \mathrm{CAs}$ from 106 sets. Scores ranged from 1.25 (supported by one species) to 15.95 (supported by 26 species). The CAs of both analyses produced many similar areas, with the second group providing finer results. Therefore, after omitting 14 CAs with lower scores, we chose the CAs mostly from the analysis with $43 \mathrm{CAs}$ in order to define the AEs. The selected CAs were those intersected with the 19 CAs from the former analysis.

The analysis with 3 deglatitude $\mathrm{x} 2.5$ deglongitude cells produced 26 CAs from 61 sets. The endemicity scores ranged from 2.066 (supported by two taxa) to 11.49 (supported by 17 taxa). Since we run the last analysis with a higher cut off, it had fewer species endemic to each CA, but their scores were higher. To define the areas of endemism, we combined the CAs from that analysis with the ones selected from the first two analyses based on their endemicity score. We summarize results in Table 1, Fig. 1, and columns 2, 3, and 4 in Fig. S1, Appendix 2.

All three analyses produced several nested and overlapping CAs and a clear split to two significant centers of endemism in the study area: the SW and the SC main consensus areas, shown of Fig. 1 (j) 2 and (j) 4.

The results of the NDM analysis with the second dataset comprising 259 species are shown in Table S1, Fig. S2. Preliminary analyses identified 22 CAs from 60 sets at grid size $1.8 \mathrm{deg}$ x $1.8 \mathrm{deg} ; 29$ CAs from 36 sets at grid size $2.7 \mathrm{deg}$ latitude/2.4deg longitude; 12 CAs at grid size 2.6deg x 2.6deg; 12 CAs at grid size $4.5 \mathrm{deg}$ x $4.5 \mathrm{deg}$; and nine CAs at grid size $5 \mathrm{deg}$ x $5 \mathrm{deg}$. Many CAs were partially overlapping and/or nested, especially in the south-central part of the study area. We found more nested CAs with the smaller cells, while larger cells yielded results with more overlap between the CAs. The results using different cell sizes with 259 species showed little variation in the CAs; therefore, we chose the EA with more CAs to supplement our discussion based on the combined analyses of the larger database with 400 species. Column 5 in Table S1, Appendix 2 includes the endemic species of 29 CAs at cell size $2.7 \mathrm{deg}$ x $2.4 \mathrm{deg}$ from the smaller database.

We discuss 27 AEs obtained for 400 species from three different cell sizes, selecting each AE under the grid size that yielded the highest number of supporting species. We present the AEs starting from the northernmost one moving southward and then eastward. A total number of species that supported an area under at least one grid size is 230 . The remaining 170 species that did not support any of the obtained AEs, are mostly widespread in parts of the study area species, e.g.Calochortus nuttalii in the western or Asclepias 
viridisin the SC/SE parts. Several species that are landscape forming in their provinces, like Ungnadia speciosa, Fallugia paradoxa, andDiospyros texana, emerged as endemics only from the analysis of smaller database with larger cells of $4.5 \mathrm{deg} \times 4.5 \mathrm{deg}$ (Fig. S1, column 5).

\subsection{The Areas of Endemism}

AE 1. Mid Rocky Mountains (Fig. 1, a1) and AE 2. E Great Basin - Rocky Mountains (Fig. 1, k1) embrace parts of the Rocky Mountain and Great Basin provinces. AE 1 is defined by four and AE 2 by three species of broadly north temperate and western North American genera. Each AE (Table 1) is supported by two species of Astragalus, a genus of Eurasian origin and migration via the BLB (Scherson et al. 2008). Eight species total (Table S1) supporting AE1 grow mostly in sagebrush scrublands, grasslands, and open conifer woodlands. Two species of Astragalus and Angelica pinnata, defining AE 2 grow in sagebrush scrublands, subalpine forests, meadows, and wetlands.

AE 3. South Rocky Mountains-Colorado Plateau-E Madrean is a large AE (Fig.1, f1) defined by four species widespread in open arid mountainous areas (Table 1). They are in SW North American genera and a madro-tethyan genus Juniperus L. Six more species of grasslands, rocky slopes, and woodland support this area in the analysis with smaller database (Table S1). In the phylogeny of Fishbein et al. (2011), Asclepias asperula endemic in AE 3 and its sister species A. viridis, which supports AE 24 South Prairie, are in the Temperate North American clade of Asclepias L. Several other species of this clade grow on the Colorado Plateau. In the phylogeny of Fishbein et al. (2018), the Sonoran Desert and Incarnatae clades are successive sisters to the remaining American Asclepias species. Another endemic in AE 3 Asclepiadaceae species, Matelea producta, is a member of the arid-adapted clade found in SW USA and northern Mexico (McDonnell et al., 2018). Several other species supporting AE 3 (Table S1) are members of SW North American clades in the genera with southern connections (e.g. Dalea ). North temperate connections among the endemics of AE3 have representatives of mostly temperate families (e.g. Rosaceae, Fagaceae). For example, the monotypic Apachian genus of montane scrublands Fallugia Endl. has a western North American ancestry (Kalkman, 2004) and the two five-species generaPetrophytum (Nutt.) Rydb. and Cercocarpus Kunth are present in western North America (C. ledifolius supports AE 1, Table S1). Within Dryadoideae of Rosaceae, a Holarctic arcto-alpine genus Dryas L., and then Purshia Raf., are successive sisters to the western North American generaChamaebatia Benth. + Cercocarpus (Sun et al., 2016). An oak species Quercus grisea endemic in AE 3 (Table S1) is a member of a small 'Arizona/North Mexico' clade in white oaks, which returned north to the USA from Mexico. Mexico has 154 species of Quercus that diversified since 14-20 Ma from an eastern North American ancestor (Hipp et al., 2018). Another example of north temperate connections comes from the genus Garrya Douglas ex Lindl. Endemic to AE 3 G. wrightii, together with two species supporting AE 20, G. ovata and G. glaberrima, are a part of a complex in the Mexican highlands/N Chihuahua (Nesom, 2012). All three species are in the subgenus Fadyenia (Endl.) Dahling, which is sister to the CFP subgenus Garrya (Burge, 2011). The genus Garrya is sister to the East Asian genus Aucuba Thunb. in the family Garryaceae, which are sister to an arctotertiary, according to Mai (1995), family Eucommiaceae. Today, Eucommiaceae consists of a single species from China, but has a wide fossil distribution in the Northern Hemisphere (Manchester et al., 2009; Soltis et al., 2018).

AE 4. Great Basin-Mohave (Fig 1, d1) includes the Mohavian subprovince and western parts of the Great Basin province. It is supported by three species of western North American or amphitropical genera found in sagebrush or creosote bush scrub, Joshua-tree woodlands, or pine forests. Eucnide urens which supports this AE in the analysis with smaller database (Table S1) represents a SW USA-Mexico-Mesoamerican genus, which was placed as the sister to the rest of the family Loasaceae (Moody et al., 2001).

AE 5. S CFP-SE Great Basin-Mohave-N Sonora (Fig.1, j1). AE 5 embraces the Mohavian subprovince and parts of the adjacent subprovinces/provinces. Four species of SW N American /amphitropical genera, which grow in open areas, sandy to rocky slopes, chaparral, and oak/pine woodlands, support this AE. Two of them are in the genusPhacelia Juss., the largest (207 sp.) and most diverse member of the family Hydrophyllaceae (Vasile et al., 2020). The family is distributed mainly in western North and South America. Hydrophyllaceae and Namaceae both appear to have originated in North America and are successively sister 
families to the remainder of the Boraginales II (Bor II) clade (Luebert et al. 2017). Another species supporting this AE in the analysis with the smaller database, Nolina bigelovii, represents the genus with 32 species half of which are endemic to Mexico (Ruiz-Sanchez et al., 2019). Geographical distribution of NolinaMichx. is split into the western and eastern ranges. The western range extends south from Utah in the north, through Baja California and the Sierra Madre Occidental. N. bigelovii, as well as N. microcarpa, which is endemic in AE 3 (Table S1), have western ranges. The eastern range of Nolina extends from Florida in the north, through the Sierra Madre Oriental south to Oaxaca in Mexico (Ruiz-Sanchez et al., 2019).

AE 6. Mohave-Sonora (Fig 1, b1). Six species, including a monotypic genus Hesperocallis A.Gray, found in the Mohavian and Sonoran subprovinces are endemic to AE 6 (Table 1). They are members of xerophytic clades of mostly SW North American genera (e.g.Cylindropuntia [Engelm.] F.M.Knuth). The Cylindropuntieae originated in the Chihuahuan Desert during the mid-Miocene and then migrated into other North American deserts. They show a consistent split between the Sonoran and Chihuahuan deserts exemplified by several Sonoran-Chihuahuan desert species pairs (Majure et al., 2019). Tiquilia plicata is another species supporting AE 6 (Table S1). It is a member of an amphitropical desert genus of the Bor II tribe Ehretieae (Gottschling et al., 2014), which is sister to the two tropical sister genera in America/Africa. Several dwarf species of Tiquilia Pers. are split between the Sonoran (subgenus Tiquilia) and Chihuahuan (subgenus Eddya) deserts. In the subgenus Tiquilia, T. plicata clade is sister to T. palmeri clade (Moore and Jansen, 2006) with T. palmeri supporting AE 7 of this study. An interesting example comes from Stephnomeria parryi of Cichorieae, Asteraceae, which is endemic to AE 6. All the principal American genera of Cichorieae radiated from a single common ancestor Phalacroseris A.Gray (Lee et al. 2003; Kilian et al. 2009), a monotypic local endemic genus in the wet meadows and upper montane forests of the Sierra Nevada Mountains. Phalacroseris is nested within the intercontinentally disjunctive Cichoriinae where it branches basally to a clade with a genus from the Horn of Africa and a mostly Mediterranean-Frontal Asian genus Cichorium L.

AE 7. South Great Basin- Mohave-N Sonora (Fig.1, g1; Table 1) is supported by three species of SW North American genera found on sandy plains and hillsides (e.g. Mohave prickly poppy), rocky slopes, creosote-bush scrub, Joshua-tree and pinyon/juniper woodlands. They are centered in the Mohave Desert extending across southern Great Basin province and northern Sonoran subprovince.

AE 8. South Sierra Nevada-Mohave (Fig. 1, 11) has three endemic species (Table 1) found on open, sandy, gravelly to rocky areas, in pinyon/juniper woodland. The area overlaps the Mohave subprovince and southern mountains in CFP, including south high Sierra-Nevada. The species supporting it are in amphitropical, mostly western North American genera (Phacelia and Cryptantha Lehmann ex G.Don). Several species of these genera are endemic in the areas partially overlapping in the super area AE 9, from AE 4 to AE 9. The majority of Phacelia species (176 spp.) is distributed in western North America (Walden et al., 2014). The center of diversity for the genus is the CFP, where a third of described taxa occur (ca. 70 spp., 40 spp. endemic). Raven and Axelrod (1995) suggest that the annual phacelias originated with the CFP during the Pliocene as early as 5.3 mya, and their ranges spread following the Eocene as more land became arid (Walden et al., 2014). An endemic to AE 7 species Cryptantha utahensis (A.Gray) Greene and two other species of series Pterocaryae form a clade with endemic to AE 8 C. mohavensis and C. gracilis Osterh (Mabry et Simpson, 2018).

AE 9. SW North American (Fig 1, j2). This super-area includes several overlapping or nested areas described above. Its endemicity index is nine, and the area is supported by 10 endemic species, including a monotypic genus Centrostegia A.Gray in Benth of Erigonoideae, Polygonaceae.

AE 10. Colorado Plateau (Fig. 1, i1). This AE overlaps southern Great Basin province in south Nevada, south Utah, and north Arizona. Two species found in semi-deserts, sandy, clayish or rocky places support this AE. One of them Tiquilia latior is sister to the endemic in AE 3 (Table S1) T. hispidissima. In the phylogeny of Moore and Jansen (2006), these species are in the subgenus Eddya, whereas endemic to AEs 6 and 7 species are in the western subgenus Tiquilia. 
Moore and Jansen (2006) suggest that the Ehretioid ancestors of Tiquilia inhabited dry tropic scrub in SW North America during the Paleocene. All current major lineages of Tiquilia likely arose in the early to mid-Miocene, perhaps evolving allopatrically in locally arid or semi-arid pockets.

AE 11. Colorado Plateau-Mohave-Colorado Desert (Fig.1, c1). This AE has a score four and is supported by two species in each of SW North American genera Brickellia Elliott and Phacelia.

AE 12. Madrean Region Montane (Fig.1, h) coincides with the Mexican Highlands province and overlays the AE 3. Seven species of broad distribution in the mountainous region are endemic to this area, among them woody species, like alligator juniper and evergreen sumac.

AE 13. Apachian-North Chihuahuan (Fig.1, l 2). The area overlays the Apachian subprovince of McLaughlin (2007) and northern part of the Chihuahuan subprovince from SE Arizona to SW Texas and northern Mexican plateau. It is supported by six species (Table 1) found on dry sandy, gravelly, rocky, and gypseous clay areas in low to mid elevations. Their ranges stretch southeastward along the northeastern Chihuahuan Subprovince to Sierra Madre Oriental. The species are members of the SW North American desert genera with tropical-subtropical American connections. A species of a mega-Mexico-Mesoamerican genus, in terms of Rzedowski (1993), Pinaropappus parvus, andAcleisanthes chenopodioides scored 1.0 each in AE 13. Acleisanthes A.Gray is a member of the North American xerophytic clade of mostly tropical/subtropical family Nyctaginaceae. It has a number of species living on gypsum-rich soils characteristic of the Chihuahuan Desert (Douglas \& Manos, 2007; Escudero et al., 2015). An endemic to this AE Thamnosma texana of an American-African genus in Rutaceae, grows on dry rocky slopes and flats. For the ancestor of Thamnosma Torr. \& Frem. a migration via the BLB from South Asia to western North America was proposed by Appelhans et al. (2016). Early diverging clades of Thamnosma were in SW North America and may have been present in the succulent biome of arid Neogene Madro-Tertiary geoflora about 34-2 Ma (Thiv et al., 2011). A single Somalian Thamnosma species that resulted from long-distance dispersal (LDD) is nested within the American clade of 15 species. In the American clade, T. texana is sister to T.montana that is endemic in AE 5. Another interesting example comes from SW USA-Mexican genusMortonia A.Gray, whose several species are endemic in different AEs (Table S1). Within Celastraceae, Mortonia is sister to the rest of Celastraceae, with strong support (Sun et al., 2016). In the phylogeny of Simmons et al. (2012), M. scabrella (AE 13) and M. greggii (AE 14) form a clade, which is sister to a clade with two Mexican species in southern Sierra Madre Oriental-Sierra Madre Del Sur provinces of Morrone et al. (2017).

AE 14. Sonoran-Chihuahuan ( Fig. 1, f 2) . This large area is nested in the mountainous AE 3; however, it is in lower elevations. Six species of wide distribution in both subprovinces of the Sonoran province give score of 5.45 (Table 1). Highest scoring species Thymophylla pentachaeta, Asteraceae frequently grows on calcareous outcrops, scrublands or deserts (FNA, v. 21). A monotypic genus Cevallia Lag. of Loasaceae is sister to a clade of two small genera in Mexico-Mesoamerica. This family has two main centers of diversity: the Andes and SW North America (Hufford, 2016), with the SW North American genus Eucnide Zucc. (E. urens supports AE 4) branching basally to the rest. Twenty-four species total support AE 14 in different analyses (Table S1). Among them are species of amphitropical genera (Larrea Cav., KoeberliniaZucc.), a Sonoran-Chihuahuan endemic genus (Cottsia Dubard \& Dop), and Ephedra. The latter genus has long been a symbol of the Tethyan flora or "flora Ephedra" (Popov, 1963). It is characterized by a Madro-Tethyan disjunction pattern and is found in all North American deserts, including in AEs 14, 15, and 23. The deepest divergences in Ephedra indicated a basal grade of species distributed in the Mediterranean area (Rydin \& Corrall, 2009). Some species of tropical-subtropical American genera (BoerhaviaL., Fuastrum E.Fourn.) in this area extend from the Sonoran subprovince northward to the western prairies and eastward to the eastern Mexican Plateau. One of them, Boerhavia spicata is a member of the North American xerophytic clade of the genus, which diversified in the deserts of SW North America (Douglas \& Manos, 2007).

AE 15. Chuhuahuan (to S Prairie). This AE (Fig. 1, d 2) encompasses the Chihuahuan subprovince, with some species extending to adjacent areas. The species supporting this area are in large genera of tropical to warm temperate regions (Phyllanthus L., Eryngium L. ), American/African (Mimosa L.), or SE North American (Lindheimera A.Gray \& Engelm.) genera. Many of the species extend north from the 
Chihuahuan Desert to south-central parts of the Prairie province. Specifically, an important element of the Madro-Tertiary chaparral vegetation, the Chihuahuan Desert speciesMahonia trifoliolata (Table S1) had a dynamic distribution range related to the Pliocene/Pleistocene climatic fluctuations (Angulo et al., 2017). It currently occupies the largest area in its history, with its northern limits reaching NE Texas. Asclepias brachystefana of AE 15 (Table 1) is in the Mexican Highands clade of the genus (Fishbein et al., 2018), while the species of Asclepias endemic to AE 3 and AE 24 are in the temperate North American clade of the genus.

AE 16. North Chihuahuan-South Texas (Fig.1 e). The area embraces northeastern part of the Chihuahuan subprovince and Texas Edwards Plateau. Three of the five species, which support this AE, have the highest score of 1.0 (Table 1). Cynanchum pringlei is in the New World clade of this tropical to warm temperate genus. It is sister to a clade across the Atlantic with center of distribution in NE Africa and Arabia. All Asclepiadeae, including Asclepias, MateleaAubl., and Cynanchum L. have an "out-of-Africa" distribution pattern (Khanum, 2016). Tiquilia gossypina is in the Chihuahuan desert subgenus Eddya (Moore and Jansen, 2006).Acleisanthes crassifolia is a species of conservation concern, found on rocky, calcareous soils in cenizo shrublands and grasslands in Coahuila, Mexico, and Texas (FNA, v.4).

AE 17. South-East Texas (Fig 1, k 2). This small area is supported by three species with narrow ranges in SE Texas. They grow on the South Texas Sand Sheet (Mimosa latidens; Carr, 2007), on limestone hills and flat open ground (Dalea lasiathera), and on gravel of limestone streambeds (Brickellia dentata) (FNA Vol. 21). Dalea is the largest and extensively radiated in the Sonoran Desert genus in the predominantly North American temperate clade Amorpheae of the legumes (Cardoso et al., 2013). Several species ofDalea support different AEs of this study (Table S1).

AE 18. South Texas-Coahuila (Fig. 1, i 2). This area is nested in AE 16 and is a part of the Chihuahuan subprovince in Coahuila and Nuevo Leon in Mexico and south Texas. It has five endemic species, including edaphic endemics on sandy soils (Funastrum torreyi) and calcareus or gypsum rich soils (Acleisanthes acutifolia).

AE 19. Chihuahuan-Tamaulpan (Fig. 1, j 3) is nested in the super area AE 22. It is supported by three species (Table 1):Viguiera stenoloba, found in Tamaulipan and Chihuahuan Desert scrub, and mostly chihuahuan, extending to Tamaulipas speciesJonstonella mexicana and Boerhavia linearifolia, found in arid grasslands or shrublands and on calcareous soils. J. mexicana represents one more tribe with the west/east split in the area of study. It is one of the four Cryptantha species of an eastern Mexico/Texas series Albidae, recently transferred to the new genus Johnstonella Brand (Simpson et al., 2019).

AE 20. Chihuahuan wide (Fig.1, a 2). This AE is supported by 11 species (Table 1) found in the Chihuahuan subprovince, sometimes extending to the east and south. They are mostly in

tropical/subtropical American genera (e.g. a common component of Chihuahuan desert scrub Condalia ericoides ), tropical/subtropical (Vachellia [Wight \& Arn.] Kuntze), and tropical/warm temperate genera with transatlantic connections (Cynanchum, Heliotropium L.). The only New World species of the MadroTethyan genusPeganum L. is restricted to the Chihuahuan Desert. Peganumis a member of a small, mostly Tethyan family Nitrariaceae of Sapindales, which includes 13 species and which diversified during the Cretaceous (Muellner-Riehl et al., 2016). The authors found that East Mediterranean-Irano-Turanian family Biebersteiniaceae (five species) and the family Nitrariaceae form a grade and have the longest stem lineages observed in Sapindales, possibly indicating that extinction may have had a greater role in shaping their extant diversity than elsewhere within the order. A good indicator of chihuahuan desert, a monotypic endemic genus Talinopsis A.Gray (Table S1) grows in desert scrub of Mexican Plateau and Trans Pecos in Texas. It is one of the four genera of a small family, which is sister to Cactaceae (Christenhusz et al., 2017), with widely disjunctive distribution in Southern Hemisphere and in the Chihuahuan Desert.

AE 21. E Madrean-Tamaulipan (Fig. 1, g 2). This AE is supported by eight species with E score of 7.04 (Table 1), found in the Sierra Madre Oriental and Tamaulipas provinces of Morrone (2017). They are in the genera with transatlantic disjunctions with the Old World, such as tropical/subtropical (Cynanchum 
, Mimosa, Cordia L.), or in tropical/subtropical American (Gochnatia Kunth, ChaptaliaVent.) genera.

AE 22. SC USA-E Madrean (Fig.1, j 4). This is a broad super area where several other areas (from AE 12 to 21) partially overlap. Twenty-one species, eleven of which have score of 1.0 support this area; E score of the area is 10 (Table 1). They are in mostly tropical/subtropical American (Guaiacum, Serjania Plum. ex Mill.), Mexican-Mesoamerican (Viguiera Kunth), or American-African (Mimosa) genera. The tropical Cordiaceae, Ehretiaceae, and Heliotropiaceae of Bor II clade have 1 species each in AEs 20 and 21, which overlap in the super area AE 22. A vegetation dominant Dermatophyllum secundiflorum, which supports AE 22, is the only widely distributed species of a small legume genus found mostly in the Chihuahuan and Sonoran subprovinces. Another woody species supporting AE 22, Diospyros texana (Table S1), is a member of a Mesoamerican-Caribbean clade of four species and is branching basally to the other species in the clade, whereas two species from its sister clade are distributed in SE Asia (Duangjai et al., 2006). Diospyros L. is one of the boreotropical (Wolfe, 1975)/paleotropical (Mai, 1995) genera of the Northern Hemisphere with intercontinental distribution in the Paleogene. The pantropical genusEhretia L. has mostly an East MadreanMesoamerican range in the New World. Its single species in the USA E. anacua supports AE 22. Currently pantropical, Ehretieae species have diversified from an American ancestor in the Early Paleogene (Luebert et al., 2016). Another species supporting this AE represents the genus Menodora Bonpl., which is the New World counterpart of Jasminum L. It is a member of the mostly Old World tropical to warm temperate tribe Jasmineae, which has a disjunction between South Africa and xeric warm temperate/subtropical North and South America (Wallander \& Albert, 2000). One more endemic, Linum vernale, belongs to the North American clade of yellow-flowered flax species derived by LDD from a western Eurasian ancestor at least 20 Mya (McDill et al., 2009).

AE 23. S Prairie (Fig. 2, b) is located north of the Apachian and Chihuahuan subprovinces and includes southern parts of the Prairie Province. It is supported by several species of North American genera (Tetraneuris Greene), with some of them extending northward from their center of origin in the SW North America/Madrean subkingdom (Asclepias, Dalea).

AE 24. Comanchian (Fig.1, b 2) partly coincides with the Comanchian chorion of McLaughlin (2007). It is supported by 16 species found throughout central/east Texas to south/central Oklahoma. The endemicity index of AE 24 is 10.07 (Table 1). Most species are in eastern North American temperate genera (Liatris Gaertn. ex Schreb., Krigia Schreb., Baptisia Vent. ), or in tropical/subtropical genera (Vernonia Schreb.). An eastern North American genistoid genus Baptisia is allied with the mostly western North American genus Thermopsis R.Br. in the Thermopsideae clade of the legumes; it had some exchange with Asia around the Bering Strait (Wang et al., 2006). Matelea is a mega-Mexico-Mesoamerican genus. With 200 species, Matelea is one of the largest genera within the Apocynaceae (McDonnell, 2015). The sister species M. biflora and $M$. cynanchoides, which support AE 24, are in the subgenus with 30 milkweeds of arid habitats centered in North Mexico (McDonnel, 2015). The genus TriodanisRaf., with two endemic species in AE 24, has a North American-Mediterranean disjunction due to an LDD event. Clade I of the Campanuloideae phylogeny of Crowl et al. (2014) contains the paraphyletic Mediterranean genus Legousia Durande and one North American clade. The Mediterranean-Frontal Asian L. falcata (Ten.) Fritsch is sister to the North American clade containing Triodanis species and a Texas endemic species Campanula reverchonii A.Gray. Some other species supporting AE 24 are endemic to a nested area that embraces S TX, EP, and BB. They are members of amphiatlantically disjunctive genera (Mimosa) or eastern North American genera (Baptisia andSilphium L.).

AE 25. Edwards Plateau (Fig. 1, c 2). This small AE is in North Central Texas and on the Edwards Plateau. It is supported by two endemic species of American-African genera, Mimosa and Tradescantia L. (Table 1).

AE 26. Atlantic and Gulf Coastal Plain (Fig. a 3). This AE is supported by three species of SE North American/Central American herbaceous genera, e.g. a monotypic genus Zygadenus Michx (Table 1). Our database containes only a few southeastern species. Analyzing in detail the woody flora of the southern Appalachians, Manos \& Meireles (2015) found mostly low-diversity clades connected to the Old World and 
a minority of New World clades.

\section{Discussion}

The analysis of the database resulted in the recognition of 26 AEs, including two super areas: SW superarea $\mathrm{AE} 9$, and SC super-area $\mathrm{AE} 22$. Two major observations consistently emerged from all the analyses: a dramatic east/west split and a significant overlap or nestedness among the adjacent AEs within each of the two disjunctive groups - the two super-areas. Szumik et al., (2018) using a dataset of mammals of North America demonstrate that AEs consistently overlap and are rarely characterized by sister taxa. Many genera (e.g. Tiquilia, Nolina,and Cylidropuntia) show a geographic split into western and eastern clades. The split to two super-areas corresponds to an environmental and physical barrier, Cochise Filter Barrier (CFB). Provost et al. (2021) studied community phylogeographic patterns of plants and animals across the CFB, which is a known transition zone between two biotas that divides the Sonoran and Chihuahuan Deserts. By synthesizing phylogeographic data for the CFB, the authors estimated that for the maximum number of species the barrier overlapped $108.6 \mathrm{deg}$. Many of the taxa they surveyed show a Pleistocene divergence time, and divergence throughout the region appeared to be a combination of forces, ranging from allopatric isolation to ecological speciation.

The endemic species of AEs $1-4$ are in north temperate or western North American genera. Many species of the SW group of overlapping areas, AEs 5 - 11, diversified in the great SW North American arid center, which Sosa et al. (2018) referred to as the center of both paleo- and neoendemism. They include members of the local xerophytic genera with extensive radiation in the Sonoran and Mohave deserts. The majority of their connections extend along the western backbone of the Americas, especially to western Mexico and to deserts in South America as amphitropical disjunctions (AAD). AAD examples throughout the angiosperms have become established via multiple asynchronous "events" with most estimated examples occurring within the last $5 \mathrm{Myr}$ (Simpson et al., 2017). Some of the endemics of the SW AEs represent the families originated in this center (e.g. Hydrophyllaceae and Namaceae). Other endemics are early-derived members of their families, such as the generaMortonia of Celastraceae and Eucnide of Loasaceae, or early-derived members of their genera (e.g. of Asclepias, Matelea, and Thamnosma). The Sonoran Desert element (e.g.Boerhavia) extends eastward to the Chihuahuan Desert into western Texas (mostly to Val Verde County) and Mexico. This supports the hypothesis of niche conservatism (Wiens \& Graham, 2005; Murphy et al., 2019), which states that endemic species will expand their range into similar environments and ecological niches. The same is true for the chihuahuan element, which extends westward to Sonora/Mohave [Larrea tridentata (Laport et al., 2012)] and eastward to Tamaulipas (Carlowrightia torreyana).

Many sampled species are included in the SW North American genera extending northward to South Rocky Mountains and western prairies. BLB served as the migration route to western North America (e.g., for Astragalus, Artemisia, and the ancestor of Thamnosma).

The endemic species of SC super area (AEs 12-22), have mostly East Madrean/Mesoamerican affinities or transatlantic connections, including with the Tethyan subkingdom (Peganum). According to Graham (2018), affinities between the SW USA/northern Mexico and the Mediterranean (ca. 15 genera of trees and shrubs; e.g., Ephedra, Juniperus, Pinus, Quercus, Styrax ; the Madrean Tethyan vegetation) is more likely the result of parallel evolution and long-distance transport than continuity of land and continuous hot and arid conditions across the northern regions anytime during the Tertiary.

A strong representation of tropical-subtropical genera (Vachellia, Diospyros ), American tropical-subtropical genera (Funastrum, Guaiacum ), and Madrean/Mesoamerican genera (Telosiphonia, Garrya) are characteristic of the SC AEs, especially of the Tamaulipan thorn scrub. The Antilles between NE South America, the Yucatan region of Mexico, and the SE USA via the Bahamas served as a filtering discontinuous stepping stone route for southern warm temperate to subtropical lineages into North America throughout their existence from about the middle Eocene to the present (Graham, 2018). Some of these made the trip but subsequently became extinct in northern North America with late Cenozoic cooling and drying (Podocarpus, Nothofagus ). An example of one taxon that persisted is Diospyros, which is the only genus of the Ebenaceae known 
in the forests of the eastern USA. Raven \& Axelrod (1974) suggest the family originated in West Gondwana and migrated into Eurasia and North America during the Paleogene (Graham, 2018). AE 24 (Comanchian) is supported by the species of the genera of E region (Baptisia, Silphium), amphiatlanticaly disjunctive genera (Desmanthus, Mimosa), and those arrived by LDDs from the Mediterranean (Lechea, Triodanis ). The Comanchian chorion of McLaughlin's system is strongly supported by our analysis, however it falls in the Prairie Province of the ER of Takhtajan's system, rather than the SW of McLaughlin. Affinities of the ER across the $\mathrm{N}$ hemisphere have been extensively discussed in the literature and reviewed by Manchester (1999), Harris et al. (2013), and Manos \& Meireles (2015).

Our analysis supports the placement of BB in the Chihuahuan subprovince of the Sonoran province of the SW, while S TX flora, which is a part of the Tamaulipas province, shows SE North American affiliation (ER). The majority of sampled prairie species also show ER affiliation. Some sampled species found in southwestern low prairies are those that extend northward from the Sonoran/Mohave deserts (in Asclepias, Dalea ) or the Chihuahuan desert (Alloberberis ) in connection with recent aridification and expansion of deserts.

\section{Conclusion}

The Sonora-Mohave arid center is among the greatest centers of xerophytic diversification and is of high conservation importance. Some very rare species are found in S TX, and this area is also highly important from the conservation perspective, as is the unique desert flora of SW Texas, already protected in two National Parks.

Our analysis is the first attempt, to the best of our knowledge, to apply NDM analysis of endemism to study distribution patterns of plant species in USA. This study has an advantage over previous qualitative classifications that the units were analyzed using species distribution data provided by the current plant specimen records. It is a step towards resolving discordances in the floristic regionalization of the SW/SC USA. The inclusion of additional species into the database in the future, expansion of the area of study, as well as additional methods for analyzing species distribution patterns should produce improved outcomes.

\section{Acknowledgments}

I thank Claudia Szumik for review and helpful comments on the manuscript. I appreciate A. Karabegov for help with the wording, J. Nelson for technical help, and M. Karabegov for final editing of the maps with Photoshop. This work was supported by grant 10-80031-3210 from the Sam Taylor Foundation.

Data accessibility: The data underlying this article are available in the Dryad Digital Repository at https://dx.doi.org/(doi:10.5061/dryad.7pvmcvdrz):

-XYD file containing point records (coordinates) for each of the species analyzed

-Excel file containing all specimen point records

-supplementary list of occurrence data downloads from GBIF

\section{References}

Aagesen L, Szumik C, Goloboff P. 2013. Consensus in the search for areas of endemism. Journal of Biogeography 40(11): 2011-2016.

Allen JM, Germain-Aubrey CC, Barve N, Neubig KM, Majure LC, Laffan SW, Mishler BD, Owens HL, Smith SA, Whitten WM, Abbott JR. 2019. Spatial phylogenetics of Florida vascular plants: the effects of calibration and uncertainty on diversity estimates. iScience 11: 7-70.

Appelhans MS, Krohm S, Manafzadeh S, Wen J. 2016. Phylogenetic placement of Psilopeganum, a rare monotypic genus of Rutaceae (the citrus family) endemic to China. Journal of Systematics and Evolution 54(5): $535-544$.

Axelrod DI. 1958. Evolution of the madro-tertiary geoflora. The Botanical Review 24(7): 433-509. 
Axelrod DI. 1975. Evolution and biogeography of Madrean-Tethyan sclerophyll vegetation. Annals of the Missouri Botanical Garden62(2): 280-334.

Baldwin BG. 2014. Origins of plant diversity in the California Floristic Province. Annual Review of Ecology, Evolution, and Systematics45: 347-369.

Baldwin BG, Thornhill AH, Freyman WA, Ackerly DD, Kling MM, Morueta-Holme N, Mishler BD. 2017. Species richness and endemism in the native flora of California. American Journal of Botany 104(3): 487501.

Bertelli S, Szumik C, Goloboff P, Giannini N, Navarro Siguenza A, Peterson T, Cracraft J. 2017. Mexican land birds reveal complexity in fine-scale patterns of endemism. Journal of Biogeography 44(8): 1836-1846.

Burge DO. 2011. Molecular phylogenetics of Garrya (Garryaceae).Madrono 58(4): 249-255.

Cardoso DB, Pennington RT, De Queiroz LP, Boatwright JS, Van Wyk BE, Wojciechowski MF, Lavin M. 2013. Reconstructing the deep-branching relationships of the papilionoid legumes. South African Journal of Botany 89: 58-75.

Casagranda MD, Taher L, Szumik C. 2012. Endemicity analysis, parsimony and biotic elements: a formal comparison using hypothetical distributions. Cladistics 28(6): 645-654.

Chacon J, Luebert F, Hilger HH, Ovchinnikova S, Selvi F, Cecchi L, Guilliams CM, Hasenstab-Lehman K, Sutory K, Simpson MG, Weigend M. 2016. The borage family (Boraginaceae s.str.): a revised infrafamilial classification based on new phylogenetic evidence, with emphasis on the placement of some enigmatic genera. Taxon 65: 523-546.

Christenhusz MJ, Fay MF, Chase MW. 2017. Plants of the world: an illustrated encyclopedia of vascular plants. Plants of the world: an illustrated encyclopedia of vascular plants.

Corral-Rosas V, Morrone, JJ. 2017. Analyzing the assembly of cenocrons in the Mexican transition zone through a time-sliced cladistic biogeographic analysis. Australian Systematic Botany 29(6): 489-501.

Correll DS, Johnston MC. 1970. Manual of the vascular plants of Texas . Renner: Texas Research Foundation.

Crisp M, Laffan S, Linder H, Monro A. 2001. Endemism in the Australian flora. Journal of Biogeography 28(2): 183-198.

Cronquist A. 1982. Map of floristic Provinces of North America.Brittonia 34: 144-145.

Crowl AA, Mavrodiev E, Mansion G, Haberle R, Pistarino A, Kamari G, Phitos D, Borsch T, Cellinese N. 2014. Phylogeny of Campanuloideae (Campanulaceae) with emphasis on the utility of nuclear pentatricopeptide repeat (PPR) genes. PLOS One 9(4): e94199.

De-Nova JA, Sanchez-Reyes LL, Eguiarte LE, Magallon S. 2018. Recent radiation and dispersal of an ancient lineage: the case of Fouquieria (Fouquiericeae, Ericales) in North American deserts. Molecular Phylogenetics and Evolution 126: 92-104.

Douglas N, Manos P. 2007. Molecular phylogeny of Nyctaginaceae: taxonomy, biogeography, and characters associated with a radiation of xerophytic genera in North America. American Journal of Botany94(5): $856-872$.

Drummond C, Eastwood R, Miotto S, Hughes C. 2012. Multiple continental radiations and correlates of diversification in Lupinus (Leguminosae): testing for key innovation with incomplete taxon sampling. Systematic Biology 61(3): 443-460.

Duangjai S, Wallnofer B, Samuel R, Munzinger J, Chase MW. 2006. Generic delimitation and relationships in Ebenaceae sensu lato: evidence from six plastid DNA regions. American Journal of Botany 93(12): $1808-1827$. 
Edler D, Guedes T, Zizka A, Rosvall M, Antonelli A. 2017. Infomapbioregions: interactive mapping of biogeographical regions from species distributions. Systematic Biology 66(2): 197-204.

Escalante T, Rodriguez G, Cao N, Ebach MC, Morrone JJ. 2007. Cladistic biogeographic analysis suggests an early Caribbean diversification in Mexico. Naturwissenschaften 94(7): 561-565.

Escalante T, Morrone JJ, Rodriguez-Tapia G. 2013. Biogeographic regions of North American mammals based on endemism. Biological Journal of the Linnean Society 110(3): 485-499.

Escudero A, Palacio S, Maestre FT, Luzuriaga AL. 2015. Plant life on gypsum: a review of its multiple facets. Biological Reviews90(1): 1-18.

Ferro I, Navarro-Siguenza AG, Morrone JJ. 2017. Biogeographical transitions in the Sierra Madre Oriental, Mexico, shown by chorological and evolutionary biogeographical affinities of passerine birds (Aves: Passeriformes). Journal of Biogeography 44(9): 2145-2160.

Fishbein M, Chuba D, Ellison C, Mason-Gamer RJ, Lynch SP. 2011. Phylogenetic relationships of Asclepias (Apocynaceae) inferred from noncoding chloroplast DNA sequences. Systematic Botany 36(4): 1008-1023.

Fishbein M, Straub SCK, Boutte J, Hansen K, Cronn RC, Listo A. 2018. Evolution at the tips: Asclepias phylogenomics and new perspectives on leaf surfaces. American Journal of Botany 105(3): 514-524.

Gamez N, Nihei SS, Scheinvar E, Morrone JJ. 2017. A temporally dynamic approach for cladistic biogeography and the processes underlying the biogeographic patterns of North American deserts. Journal of Zoological Systematics and Evolutionary Research . 55(1):11-8.

Gandhi KN, Vincent MA, Reveal JL. 2011. Dermatophyllum, the correct name for Calia (Fabaceae). Phytoneuron 57: 1-4.

Goloboff P. 2004. NDM/VNDM: programs for identification of areas of endemism (Version 3.0) [Software last accessed 08/2020]. Disponible en. http://www.lillo.org.ar/phylogeny/endemism.

Goloboff P. 2016. NDM and VNDM: programs for the identification of areas of endemism, vers. 3.1. Program and documentation. www.lillo.org.ar/phylogeny.

Gottschling M, Luebert F, Hilger HH, Mille, JS. 2014. Molecular delimitations in the Ehretiaceae (Boraginales). Molecular Phylogeneics and Evolution 72(1): 1-6.

Graham A. 2018. The role of land bridges, ancient environments, and migrations in the assemblyof the North American flora. Journal of Systematics and Evolution 56(5), pp.405-429.

Halffter G, Morrone JJ. 2017. An analytical review of Halffter's Mexican transition zone, and its relevance for evolutionary biogeography, ecology and biogeographical regionalization. Zootaxa 4226(1): 1-46.

Harris AJ, Wen J, Xiang QY. 2013. Inferring the biogeographic origins of inter-continental disjunct endemics using a Bayes-DIVA approach.Journal of Systematics and Evolution 51(2): 117-133.

Hijmans RJ, Cameron SE, Parra JL, Jones PG, Jarvis A. 2005. Very high resolution interpolated climate surfaces for global land areas.International Journal of Climatology: A Journal of the Royal Meteorological Society 25(15): 1965-1978.

Hipp, AL, Manos PS, Gonzalez-Rodriguez A, Hahn M, Kaproth M, McVay JD, Avalos SV, Cavender-Bares J. 2018. Sympatric parallel diversification of major oak clades in the Americas and the origins of Mexican species diversity. New Phytologist 217(1): 439-452.

Carr W. 2007. http://w3.biosci.utexas.edu/prc/DigFlora/WRC/Carr-SandSheet.html

Hufford L. 2016. Loasaceae. In: Flora of North America Editorial Committee, ed. Flora of North America North of Mexico . New York and Oxford: Oxford University Press, 491-492. 
Jepson Flora Project (eds.) 2021, Jepson eFlora, https://ucjeps.berkeley.edu/eflora/, accessed on May 02, 2021.

Kalkman C. 2004. Rosaceae. In: Kubitzki K, Rohwer JG, Bittrich V, editors. Flowering plants* dicotyledons . Berlin and Heidelberg: Springer, 343-386.

Kamelin RV. 1973. Florogeneticheskiy analyz estestvennoy flori Gornoy Sredney Azii [Florogenetic analysis of the native flora of the Montane Middle Asia] . Leningrad: Nauka (In Russian).

Kamelin RV. 1998. Altai Mountain country (Contributions to the history of the flora of Asia) . Barnaul, Russia: Altai State University Press (In Russian).

Katinas L, Crisci JV, Wagner WL, Hoch PC. 2004. Geographical diversification of tribes Epilobieae, Gongylocarpeae, and Onagreae (Onagraceae) in North America, based on parsimony analysis of endemicity and track compatibility analysis. Annals of the Missouri Botanical Garden 91(1): 159-185.

Kartesz JT. 2016. Floristic synthesis of North America, Version 1.0. Biota of North America Program (BONAP).

Khanum R, Surveswaran S, Meve U, Liede-Schumann S. Cynanchum (Apocynaceae: Asclepiadoideae): a pantropical Asclepiadoid genus revisited. 2016. Taxon. 65(3):467-86.

Kilian N, Gemeinholzer B, Lack HW. 2009: Tribe Cichorieae. In: Funk V.A., A. Susanna, T.E. Stuessy, \& R.J. Bayer, eds.

Systematics, evolution and biogeography of Compositae, IAPT, Vienna, Austria. Pp. 343-383.

Kreft H, Jetz W. 2010. A framework for delineating biogeographical regions based on species distributions. Journal of Biogeography37(11): 2029-2053.

Kubitzki K. 2004. Rosaceae. In: Kubitzki K, Rohwer JG, Bittrich V, eds. The families and genera of vascular plants . Berlin, Germany: Springer-Verlag, 343-386.

Laport RG, Minckley RL, Ramsey J. 2012. Phylogeny and cytogeography of the North American creosote bush (Larrea tridentata, Zygophyllaceae).Systematic Botany .1;37(1):153-64.

Lee J, Baldwin BG, Gottlieb LD. 2003. Phylogenetic relationships among the primarily North American genera of Cichorieae (Compositae) based on analysis of 18S-26S Nuclear rDNA ITS and ETS Sequences. Syst. Bot. 28(3):61-626.

Linder HP. 2001. On areas of endemism, with an example from the African Restionaceae. Systematic biology 50(6):892-912.

Linder HP, de Klerk HM, Born J, Burgess ND, Fjeldsa J, Rahbek C. 2012. The partitioning of Africa: statistically defined biogeographical regions in sub-Saharan Africa. Journal of Biogeography 39(7): 11891205 .

Link-Perez M, Laffan S. 2018. Fern and lycophyte diversity in the Pacific Northwest: patterns and predictors. Journal of Systematics and Evolution 56(5): 498-522.

Lonard RI, Everitt JH, Judd FW. 1991. Woody plants of the Lower Rio Grande, Texas . Texas: Texas Memorial Museum, the University of Texas.

Luebert F, Couvreur TLP, Gottschling M, Hilger HH, Miller JS, Weigend M. 2016. Historical biogeography of Boraginales: West Gondwanan vicariance followed by long-distance dispersal? Journal of Biogeography44(1): $158-169$.

Mai DH. 1991. Palaeofloristic changes in Europe and the confirmation of the Arctotertiary-Palaeotropical geofloral concept. Review of Palaeobotany and Palynology 68(1-2): 29-36.

Mai DH. 1995. Tertiare vegetationsgeschichte Europas . Jena, Germany: Gustav Fischer. 
Majure LC, Baker MA, Cloud-Hughes M, Salywon A, Neubig KM. 2019. Phylogenomics in Cactaceae: a case study using the chollas sensu lato (Cylindropuntieae, Opuntioideae) reveals a common pattern out of the Chihuahuan and Sonoran deserts. American Journal of Botany106(10): 1327-1345.

Manchester SR. 1999. Biogeographical relationships of North American tertiary floras. Annals of the Missouri Botanical Garden 86(2): 472-522.

Manchester SR, Chen ZD, Lu AM, Uemura K. 2009. Eastern Asian endemic seed plant genera and their paleogeographic history throughout the Northern Hemisphere. Journal of Systematics and Evolution 47(1): $1-42$.

Manos PS, Meireles JE. 2015. Biogeographic analysis of the woody plants of the Southern Appalachians: implications for the origins of a regional flora. American Journal of Botany 102(5): 780-804.

McDill J, Repplinger M, Simpson BB, Kadereit JW. 2009. The phylogeny of Linum and Linaceae subfamily Linoideae, with implications for their systematics, biogeography, and evolution of heterostyly.Systematic Botany 34(2): 386-405.

McDonnell A. 2015. Non-twining milkweed vines of Oklahoma: an overview of Matelea biflora and Matelea cynanchoides (Apocynaceae).Oklahoma Native Plant Record 67(14): 67-79.

McDonnell A, Parks M, Fishbein M. 2018. Multilocus phylogenetics of New World milkweed vines (Apocynaceae, Asclepiadoideae, Gonolobinae).Systematic Botany 43(1): 77-96.

McLaughlin SP. 2007. Tundra to tropics: the floristic plant geography of North America . Fort Worth: Botanical Research Institute of Texas.

Mercado Gomez J, Escalante T. 2018. Areas of endemism of the Neotropical species of Capparaceae. Biological Journal of the Linnean Society126(3): 507-520.

Mishler BD, Guralnick R, Soltis PS, Smith SA, Soltis DE, Barve N, Allen JM, Laffan SW. 2020. Spatial phylogenetics of the North American flora.Journal of Systematics and Evolution. 58(4):393-405.

Moody ML, Hufford L, Soltis DE, Soltis PS. 2010. Phylogenetic relationships of Loasaceae subfamily Gronovioideae inferred from matK and ITS sequence data.

American Journal of Botany 88(2): 326-336.

Moore MJ, Jansen RK. Molecular evidence for the age, origin, and evolutionary history of the American desert plant genus Tiquilia (Boraginaceae). Molecular Phylogenetics and Evolution. 2006 Jun 1;39(3):668-87.

Moore MJ, Tye A, Jansen RK. 2006. Patterns of long-distance dispersal in Tiquilia subg. Tiquilia (Boraginaceae): implications for the origins of amphitropical disjuncts and Galapagos Islands endemics. American Journal of Botany 93(8): 1163-1177.

Morrone JJ. 1994. On the identification of areas of endemism.Systematic Biology 43(3): 438-441.

Morrone JJ. 2009. Evolutionary biogeography: an integrative approach with case studies . New York: Columbia University Press.

Morrone JJ. 2010. Fundamental biogeographic patterns across the Mexican Transition Zone: an evolutionary approach. Ecography 33: 355-361.

Morrone JJ. 2014. Biogeographical regionalization of the Neotropical region. Zootaxa 3782: 1-110.

Morrone JJ. 2015. Halffter's Mexican transition zone (1962-2014), cenocrons and evolutionary biogeography. Journal of Zoological Systematics and Evolutionary Research 53(3): 249-257.

Morrone JJ. 2018. The spectre of biogeographical regionalization. Journal of Biogeography 45(2); 1-7. 
Morrone, JJ, Escalante T, Rodriguez-Tapia G. 2017. Mexican biogeographic Provinces: map and shapefiles. Zootaxa 4277(2): 277-279.

Morrone JJ, Marquez J. 2001. Halffter's Mexican transition zone, beetle generalized tracks, and geographical homology. Journal of Biogeography 28: 635-650.

Munguia-Lino G, Escalante T, Morrone JJ, Rodriguez A. 2016. Areas of endemism of the North American species of Tigridieae (Iridaceae).Australian Systematic Botany 29(2): 142-156.

Murphy DJ, Ebach MC, Miller JT, Laffan SW, Cassis G, Ung V, Tursky ML. 2019. Do phytogeographic patterns reveal biomes or biotic regions? Cladistics 35(6):654-70.

Nesom GL. 2012. Notes on the Garrya ovata (Garryaceae) complex.Phytoneuron 97: 1-6.

Oliveira U, Brescovit AD, Santos AJ. 2015. Delimiting areas of endemism through kernel interpolation. PLoS One 10(1): e0116673.

Olivero J, Real R, Marquez AL. 2011. Fuzzy chorotypes as a conceptual tool to improve insight into biogeographic patterns. Systematic Biology 60(5): 645-660.

Phillips SJ, Anderson RP, Schapire RE. 2006. Maximum entropy modeling of species geographic distributions. Ecological Modelling 190(3-4): 231-259.

Phillips S, Dudik M, Schapire R. Maxent software for modeling species niches and distributions (Version 3.4.1). http://biodiversityinformatics.amnh.org/open_source/maxent/.

Pinilla-Buitrago GE, Escalante T, Gutierrez-Velazquez A, Reyes-Castillo P, Rojas-Soto OR. 2018. Areas of endemism persist through time: a palaeoclimatic analysis in the Mexican Transition Zone. Journal of Biogeography 45(4): 952-961.

Popov MG. 1963. Osnovy florogenetiki [Fundamentals of florogenetics] . Moscow: Izd-vo Akademii nauk SSSR [USSR Academy of Sciences] (In Russian).

Popov MG. 1983. Phylogeny, florogenetics, florography, and systematics. Selected works (Vols. 1-2) . Kiuev: Naykova Dumka (In Russian).

Powell AM. 1998. Trees and shrubs of the Trans-Pecos and adjacent areas . Austin: University of Texas Press.

Powell AM, Worthington RD. 2018. Flowering plants of Trans-Pecos and adjacent areas. BRIT.

QGIS Development Team 2019. QGIS Geographic Information System. Open Source Geospatial Foundation Project. http://qgis.osgeo.org.

Provost KL, Myers EA, Smith BT. 2021. Community phylogeographic patterns reveal how a barrier filters and structures taxa in North American warm deserts. Journal of Biogeography . 13.

Raven PH, Axelrod DL. 1974. Angiosperm biogeography and past continental movements. Annals of the Missouri Botanical Garden 61: 539-673.

Raven PR, Axelrod DL. 1995. Origin and relationships of the California flora. Berkeley: University of California Press.

Rodriguez A, Castro-Castro A, Vargas-Amado G, Vargas-Ponce O, Zamora-Tavares P, Gonzalez-Gallegos J, Carrillo-Reyes P, Anguiano-Constante M, Carrasco-Ortiz M, Garcia-Martinez M, Gutierrez-Rodriguez B. 2018. Richness, geographic distribution patterns, and areas of endemism of selected angiosperm groups in Mexico.Journal of Systematics and Evolution 56(5): 537-549.

Rzedowski J. 1978. Vegetacion de Mexico . Mexico, D.F.: Editorial Limusa. 
Rzedowski J. 1993. Diversity and origins of phanerogamic flora of Mexico. In: Ramamoorthy TP, Bye R, Lot A, Fa J, eds. Biological diversity of Mexico: origins and distribution. New York: Oxford University Press, $129-147$.

Ruiz-Sanchez E, Carrillo-Reyes P, Hernandez-Sandoval LG, Specht CD. 2019. Two new species of Nolina (Nolinoideae: Asparagaceae) endemic to Western Mexico. Phytotaxa 400(4): 187-198.

Saghatelyan AA. 2009. A classification of geographic elements and analysis of the flora of Big Bend region of Texas. Journal of the Botanical Research Institute of Texas 3(1): 407-441.

Saghatelyan AA. 2015. Phytogeographical relationships and analysis of the flora of South-Central Texas USA Journal of the Botanical Research Institute of Texas 9(1): 259-294.

Saghatelyan AA. 2017. Phytogeographical relationships and analysis of the flora of South Texas Plains, USA. Journal of the Botanical Research Institute of Texas 11(2): 527-561.

SEINet Portal Network. 2020. http//:swbiodiversity.org/seinet/index.php [accessed on 3.1.2020].

Simpson B, Weeks A, Helfgott M, Larkin L. 2004. Species relationships in Krameria (Krameriaceae) based on ITS sequences and morphology: implications for character utility and biogeography. Sysematic Botany 29(1): $97-108$.

Simpson MG, Mabry ME, Hasenstab-Lehman KR. 2019. Transfer of four species of Cryptantha to the genus Johnstonella (Boraginaceae).Phytotaxa. 12:425 (5):279-89.

Michael G. Simpson, C. Matt Guilliams, Leigh A. Johnson, Patterns and processes of American amphitropical disjunctions: New insights, American Journal of Botany, 10.3732/ajb.1700433, 104, 11, (1597-1599), (2017).

Soltis D, Soltis P, Endress P, Chase MW, Manchester S, Judd W, Majure L, Mavrodiev E. 2018. Phylogeny and evolution of the angiosperms: revised and updated edition . Chicago: University of Chicago Press.

Sosa V, De-Nova JA. 2012. Endemic angiosperm lineages in Mexico: hotspots for conservation. Acta Botanica Mexicana 100: 293-315.

Sosa V, De-Nova JA, Vasquez-Cruz M. 2018. Evolutionary history of the flora of Mexico: dry forests cradles and museums of endemism. Journal of Systematics and Evolution 56(5): 523-536.

Sosa V, Vasquez-Cruz M, Villarreal-Quintanilla JA. 2020. Influence of climate stability on endemism of the vascular plants of the Chihuahuan Desert. Journal of Arid Environments 177: 104139.

Sun M, Naeem R, Su JX, Cao, ZY, Burleigh JG, Soltis PS, Soltis DE, Chen ZD. 2016. Phylogeny of the Rosidae: a dense taxon sampling analysis. Journal of Systematics and Evolution 54(4): 363-391.

Szumik C, Cuezzo F, Goloboff P, Chalup A. 2002. An optimality criterion to determine areas of endemism. Systematic Biology 51(5): 806-816.

Szumik C, Goloboff P. 2004. Areas of endemism: an improved optimality criterion. Systematic Biology 53(6): 968-977.

Szumik C, Pereyra, V, Casagranda D. 2018. Areas of endemism: to overlap or not to overlap, that is the question. Cladistics 35(2): 198-229.

Takhtajan, AL. 1978. The floristic regions of the world . Leningrad: Nauka (In Russian).

Takhtajan, AL. 1986. Floristic regions of the world . Berkeley: University of California Press.

Thiv M, Van Der Niet T, Rutschmann F, Thulin M, Brune T, Linder HP. 2011. Old-New World and trans-African disjunctions of Thamnosma (Rutaceae): intercontinental long-distance dispersal and local differentiation in the succulent biome. American Journal of Botany 98(1): 76-87. 
Thorne RF. 1993. Phytogeography. In: North America Editorial Committee, ed. Flora of North America (Vol. 1 ). New York: Oxford University Press, 132-153.

Thornhill A, Baldwin BG, Freyman WA, Nosratinia S, Kling MM, Morueta-Holme N, Madsen TP, Ackerly DD, Mishler BD. 2017. Spatial phylogenetics of the native California flora. BMC Biology 15(1): 96.

Turner BL, Nichols H, Denny GC, Doron O. 2003. Atlas of the vascular plants of Texas. Sida Botanical Miscellany 24. Vol. 1: 648 pp.

Turrill WB. 1958. The evolution of floras with special reference to those of the Balkan Peninsula. Journal of the Linnaean Society, London (Bot.) 56(356): 136-152.

Maria-Anna Vasile, Julius Jeiter, Maximilian Weigend \& Federico

Luebert (2020): Phylogeny and historical biogeography of Hydrophyllaceae and Namaceae,

with a special reference to Phacelia and Wigandia, Systematics and Biodiversity,

Vasquez-Cruz M, Sosa V. 2019. Assembly and origin of the flora of the Chihuahuan Desert: the case of sclerophyllous Rosaceae. Journal of Biogeography 47(2): 445-459.

Vilhena DA, Antonelli A. 2015. A network approach for identifying and delimiting biogeographical regions. Nature Communications 6: 6848.

Wallander E, Albert V. 2000. Phylogeny and classification of Oleaceae based on RPS16 and TRNL-F sequence data. American Journal of Botany 87(12): 1827-1841.

Wang HC, Sun H, Compton JA, Yang JB. 2006. A phylogeny of Thermopsideae (Leguminosae: Papilionoideae) inferred from nuclear ribosomal internal transcribed spacer (ITS) sequences. Botanical Journal of the Linnaean Society 151(3): 365-373.

Wang S, Boru BH, Njogu AW, Ochola AC, Hu G, Zhou Y, Wang Q. 2019. Floristic composition and endemism pattern of vascular plants in Ethiopia and Eritrea. Journal of Systematics and Evolution 58(1): $33-42$.

Wen J, Ickert-Bond S. 2009. Evolution of the Madrean-Tethyan disjunctions and the North and South American amphitropical disjunctions in plants. Journal of Systematics and Evolution 47(5): 331-348.

Wen J, Nie Z, Ickert-Bond S. 2016. Intercontinental disjunctions between eastern Asia and western North America in vascular plants highlight the biogeographic importance of the Bering land bridge from late Cretaceous to Neogene. Journal of Systematics and Evolution 54(5): 469-490.

Walden G, Garrison L, Spicer G, Cipriano F, \& Patterson R. (2014). Phylogenies and chromosome evolution of Phacelia (Boraginaceae: Hydrophylloideae) inferred from nuclear ribosomal and chloroplast sequence data. Madrono, 61 (1), 16-47.

Wiens JJ, Graham CH. 2005. Niche conservatism: integrating evolution, ecology, and conservation biology. Annual Review of Ecology, Evolution, and Systematics 36: 519-539.

Wolfe JA. 1975. Some aspects of plant geography of the Northern Hemisphere during the late Cretaceous and Tertiary. Annals of the Missouri Botanical Garden 62(2): 264-279.

Ye J, Lu L, Liu B, Yang T, Zhang J, Hu H, Li R, Lu A, Liu H, Mao L, Chen Z. 2019. Phylogenetic delineation of regional biota: a case study of the Chinese flora. Molecular Phylogenetics and Evolution 135: 222-229.

Zhang G, Slik JF, Ma KP. 2016. Using species distribution modeling to delineate the botanical richness patterns and phytogeographical regions of China. Scientific Reports 6(1): 1-9.

Table 1. Areas of endemism, numbers of species and species supporting each AE obtained for 400 sp. under cell sizes 3deglat. x 2.5deglong., 3deglat. x 1.5deglong, and 2.5 deglat. x 1.5 deglong. 


\begin{tabular}{|c|c|c|c|c|c|c|c|}
\hline $\mathrm{AE}$ & $\mathrm{CA}$ & $\begin{array}{l}\text { Cell: } \text { Lat }^{\circ} \mathrm{x} \\
\text { Long }^{\circ}\end{array}$ & $\begin{array}{l}\text { Endemicity } \\
\text { Score (E) }\end{array}$ & End. Ssp. & $\begin{array}{l}\text { Species } \\
\text { Giving Score } \\
\text { (endemicity } \\
\text { score) }\end{array}$ & Ind. AEs & Map \\
\hline $\begin{array}{l}\text { 1. Mid } \\
\text { Rocky Mt }\end{array}$ & 2 & $3 \times 1.5$ & $\begin{array}{l}2.16875- \\
2.41875\end{array}$ & 4 & $\begin{array}{l}\text { Astragalus } \\
\text { cibarius } \\
\text { (0.700- } \\
0.868) \\
\text { Astragalus } \\
\text { utaensis } \\
\text { (0.000- } \\
0.714) \\
\text { Bal- } \\
\text { samorhyza } \\
\text { macrophylla } \\
\text { (0.684-.733) } \\
\text { Androsace } \\
\text { filiformis } \\
\text { (0.000- } \\
0.700)\end{array}$ & 4 & Fig .1 (a) 1 \\
\hline $\begin{array}{l}\text { 2. E Great } \\
\text { Basin - } \\
\text { Rocky Mt }\end{array}$ & 27 & 更 & $\begin{array}{l}2.26467- \\
2.51467\end{array}$ & 3 & $\begin{array}{l}\text { Astragalus } \\
\text { agrophyllus } \\
\text { (0.780) } \\
\text { Astragalus } \\
\text { kentrophyta } \\
\text { (0.778) } \\
\text { Angelica } \\
\text { pinnata } \\
(0.707)\end{array}$ & 1 & Fig .1 (k) 1 \\
\hline $\begin{array}{l}\text { 3. S Rocky } \\
\text { Mt } \\
\text {-Colorado } \\
\text { Plateau-E } \\
\text { Madrean }\end{array}$ & 15 & $3 \times 2.5$ & $\begin{array}{l}2.45162- \\
2.68962\end{array}$ & 4 & $\begin{array}{l}\text { Gutierrezia } \\
\text { microcephala } \\
\text { (0.821- } \\
\text { 0.833) } \\
\text { Allionia } \\
\text { incarnata } \\
\text { var. } \\
\text { incarnata } \\
\text { (0.000- } \\
\text { 0.800) } \\
\text { Baileya } \\
\text { multiradiata } \\
\text { (0.82\%- } \\
\text { 0.840) } \\
\text { Juniperus } \\
\text { monosperma } \\
\text { (0.000- } \\
\text { 0.804) }\end{array}$ & 2 & Fig. 1 (f) 1 \\
\hline
\end{tabular}




\begin{tabular}{|c|c|c|c|c|c|c|c|}
\hline $\mathrm{AE}$ & $\mathrm{CA}$ & $\begin{array}{l}\text { Cell: } \text { Lat }^{\circ} \mathrm{x} \\
\text { Long }^{\circ}\end{array}$ & $\begin{array}{l}\text { Endemicity } \\
\text { Score (E) }\end{array}$ & End. Ssp. & $\begin{array}{l}\text { Species } \\
\text { Giving Score } \\
\text { (endemicity } \\
\text { score) }\end{array}$ & Ind. AEs & Map \\
\hline $\begin{array}{l}\text { 4. Great } \\
\text { Basin } \\
\text {-Colorado } \\
\text { Plateau- } \\
\text { Mohave-N } \\
\text { Sonora }\end{array}$ & 16 & $3 \times 1.5$ & $\begin{array}{l}2.52975- \\
2.77975\end{array}$ & 3 & $\begin{array}{l}\text { Hymenoxys } \\
\text { cooperii } \\
\text { (1.000) } \\
\text { Hymenoxys } \\
\text { lemmonii } \\
\text { (0.706) } \\
\text { Cryptantha } \\
\text { recurvata } \\
(0.824)\end{array}$ & 1 & Fig. 1 (d) 1 \\
\hline $\begin{array}{l}\text { 5. S } \\
\text { CFP-SE } \\
\text { Great } \\
\text { Basin - } \\
\text { Mohave - } \\
\text { N Sonora }\end{array}$ & 5 & 更 & $\begin{array}{l}3.31250- \\
3.56250\end{array}$ & 4 & $\begin{array}{l}\text { Encelia } \\
\text { actoni } \\
\text { (0.875) } \\
\text { Chorizanthe } \\
\text { corrugata } \\
\text { (0.813) } \\
\text { Phacelia } \\
\text { curvipes } \\
\text { (0.813) } \\
\text { Phacelia } \\
\text { lemmonii } \\
\text { (0.813) }\end{array}$ & 1 & Fig. 1 (j) 1 \\
\hline $\begin{array}{l}\text { 6. Mohave } \\
\text { - Sonora }\end{array}$ & 8 & $3 \times 2.5$ & $\begin{array}{l}4.07143- \\
4.41667\end{array}$ & 6 & $\begin{array}{l}\text { Hesperocallis } \\
\text { undulata } \\
\text { (0.000- } \\
\text { 1.000) } \\
\text { Grusonia } \\
\text { kunzei } \\
\text { (0.833- } \\
\text { 1.000) } \\
\text { Gaillardia } \\
\text { arizonica } \\
\text { (0.833- } \\
\text { 1.000) } \\
\text { Brickellia } \\
\text { desertorum } \\
\text { (0.000- } \\
\text { 0.917) } \\
\text { Cylindrop- } \\
\text { untia } \\
\text { acanthocarpa } \\
\text { (0.000- } \\
\text { 0.917) } \\
\text { Baileya } \\
\text { pauciradiata } \\
\text { (0.000- } \\
\text { 0.833) }\end{array}$ & 3 & Fig. 1 (b) 1 \\
\hline
\end{tabular}




\begin{tabular}{|c|c|c|c|c|c|c|c|}
\hline $\mathrm{AE}$ & $\mathrm{CA}$ & $\begin{array}{l}\text { Cell: } \text { Lat }^{\circ} \mathrm{x} \\
\text { Long }^{\circ}\end{array}$ & $\begin{array}{l}\text { Endemicity } \\
\text { Score (E) }\end{array}$ & End. Ssp. & $\begin{array}{l}\text { Species } \\
\text { Giving Score } \\
\text { (endemicity } \\
\text { score) }\end{array}$ & Ind. AEs & Map \\
\hline $\begin{array}{l}\text { 7. S Great } \\
\text { Basin - } \\
\text { Mohave - } \\
\text { N Sonora }\end{array}$ & 9 & $3 \times 2.5$ & $\begin{array}{l}3.37400- \\
3.06100\end{array}$ & 3 & $\begin{array}{l}\text { Cryptantha } \\
\text { utahensis } \\
\text { (0.938) } \\
\text { Phacelia } \\
\text { rotundifolia } \\
\text { (0.938) } \\
\text { Argemone } \\
\text { corymbosa } \\
\text { (0.938) }\end{array}$ & 1 & Fig. 1 (g) 1 \\
\hline $\begin{array}{l}\text { 8. S Sierra } \\
\text { Nevada - } \\
\text { Mohave }\end{array}$ & 43 & $3 \times 1.5$ & $\begin{array}{l}3.00000- \\
3.25000\end{array}$ & 3 & $\begin{array}{l}\text { Cryptantha } \\
\text { mohavensis } \\
\text { (1.000) } \\
\text { Phacelia } \\
\text { mohavensis } \\
\text { (1.000) } \\
\text { Phacelia } \\
\text { austromon- } \\
\text { tana } \\
(1.000)\end{array}$ & 1 & Fig. 1 (l) 1 \\
\hline
\end{tabular}




\begin{tabular}{|c|c|c|c|c|c|c|c|}
\hline $\mathrm{AE}$ & $\mathrm{CA}$ & $\begin{array}{l}\text { Cell: } \text { Lat }^{\circ} \mathrm{x} \\
\text { Long }^{\circ}\end{array}$ & $\begin{array}{l}\text { Endemicity } \\
\text { Score (E) }\end{array}$ & End. Ssp. & $\begin{array}{l}\text { Species } \\
\text { Giving Score } \\
\text { (endemicity } \\
\text { score) }\end{array}$ & Ind. AEs & Map \\
\hline $\begin{array}{l}\text { 9. SW N } \\
\text { America }\end{array}$ & 6 & $3 \times 2.5$ & $\begin{array}{l}9.09774- \\
8.90200\end{array}$ & 10 & $\begin{array}{l}\text { Centrostegia } \\
\text { thurberi } \\
\text { (0.864- } \\
\text { 1.000) } \\
\text { Chorizanthe } \\
\text { rigida } \\
\text { (0.864- } \\
\text { 1.000) } \\
\text { Eschscholzia } \\
\text { minutiflora } \\
\text { (0.000- } \\
\text { 0.808) } \\
\text { Cylindrop- } \\
\text { untia } \\
\text { acanthocarpa } \\
\text { (0.000- } \\
\text { 0.813) } \\
\text { Cylindrop- } \\
\text { untia } \\
\text { echinocarpa } \\
\text { (0.000- } \\
\text { 0.864) } \\
\text { Cylindrop- } \\
\text { untia } \\
\text { ramosissima } \\
\text { (0.818- } \\
\text { 0.939) } \\
\text { Grusonia } \\
\text { parishii } \\
\text { (0.000- } \\
\text { 0.813) } \\
\text { Phacelia } \\
\text { cryptantha } \\
\text { (0.000- } \\
\text { 0.909) } \\
\text { Phacelia } \\
\text { fremontii } \\
\text { (0.000- } \\
\text { 0.818) } \\
\text { Brickellia } \\
\text { atractyloides } \\
\text { (0.818- } \\
\text { 0.938) }\end{array}$ & 3 & $\begin{array}{l}\text { Fig. } 1 \text { (j) } 2 \\
\text { Fig. } 2 \text { (a) }\end{array}$ \\
\hline
\end{tabular}




\begin{tabular}{|c|c|c|c|c|c|c|c|}
\hline $\mathrm{AE}$ & $\mathrm{CA}$ & $\begin{array}{l}\text { Cell: } \text { Lat }^{\circ} \mathrm{x} \\
\text { Long }^{\circ}\end{array}$ & $\begin{array}{l}\text { Endemicity } \\
\text { Score (E) }\end{array}$ & End. Ssp. & $\begin{array}{l}\text { Species } \\
\text { Giving Score } \\
\text { (endemicity } \\
\text { score) }\end{array}$ & Ind. AEs & Map \\
\hline $\begin{array}{l}10 . \\
\text { Colorado } \\
\text { Plateau }\end{array}$ & 23 & $3 \times 2.5$ & $\begin{array}{l}2.00000- \\
2.25000\end{array}$ & 2 & $\begin{array}{l}\text { Tiquilia } \\
\text { latior } \\
(1.000) \\
\text { Encelia } \\
\text { resinifera } \\
\text { (1.000) }\end{array}$ & 1 & Fig. 1 (i) 1 \\
\hline $\begin{array}{l}11 . \\
\text { Colorado } \\
\text { Plateau - } \\
\text { Mohave - } \\
\text { Colorado } \\
\text { Desert }\end{array}$ & 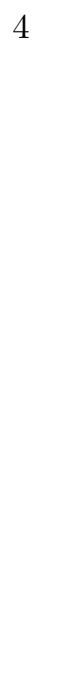 & $3 \times 2.5$ & $\begin{array}{l}1.75000- \\
2.00000\end{array}$ & 4 & $\begin{array}{l}\text { Brickellia } \\
\text { incana } \\
(0.833 \\
-1.000) \\
\text { Brickellia } \\
\text { longifolia } \\
\text { (0.000- } \\
1.000) \\
\text { Phacelia } \\
\text { neglecta } \\
\text { (0.000- } \\
1.000) \\
\text { Phacelia } \\
\text { parishii } \\
\text { (0.000- } \\
1.000)\end{array}$ & 4 & $\begin{array}{l}\text { Fig. } 1 \text { (c) } 1 \\
\text { blue }\end{array}$ \\
\hline $\begin{array}{l}12 . \\
\text { Madrean } \\
\text { Region } \\
\text { Montane }\end{array}$ & 25 & $3 \times 1.5$ & $\begin{array}{l}6.77443- \\
7.02443\end{array}$ & 7 & $\begin{array}{l}\text { Rhus virens } \\
\text { (0.892) } \\
\text { Rhus } \\
\text { microphylla } \\
\text { (0.775) } \\
\text { Cologania } \\
\text { angustifolia } \\
\text { (0.816) } \\
\text { Cylindrop- } \\
\text { untia } \\
\text { leptocaulis } \\
\text { (0.786) } \\
\text { Tiquilia } \\
\text { canescens } \\
\text { (0.750) } \\
\text { Juniperus } \\
\text { deppeana } \\
\text { (0.738) } \\
\text { Nama } \\
\text { hispida } \\
\text { (0.714) }\end{array}$ & 1 & Fig. $1(\mathrm{~h})$ \\
\hline
\end{tabular}




\begin{tabular}{|c|c|c|c|c|c|c|c|}
\hline $\mathrm{AE}$ & $\mathrm{CA}$ & $\begin{array}{l}\text { Cell: } \text { Lat }^{\circ} \mathrm{x} \\
\text { Long }^{\circ}\end{array}$ & $\begin{array}{l}\text { Endemicity } \\
\text { Score (E) }\end{array}$ & End. Ssp. & $\begin{array}{l}\text { Species } \\
\text { Giving Score } \\
\text { (endemicity } \\
\text { score) }\end{array}$ & Ind. AEs & Map \\
\hline $\begin{array}{l}13 . \\
\text { Apache- N } \\
\text { Chi- } \\
\text { huahuan }\end{array}$ & 6 & $2.5 \times 1.5$ & $\begin{array}{l}2.96429- \\
3.29167\end{array}$ & 6 & $\begin{array}{l}\text { Pinaropappus } \\
\text { parvus } \\
\text { (0.700- } \\
\text { 1.000) } \\
\text { Acleisanthes } \\
\text { chenopodi- } \\
\text { oides } \\
\text { (0.000- } \\
\text { 1.000) } \\
\text { Porophyllum } \\
\text { scoparium } \\
\text { (0.000- } \\
\text { 0.857) } \\
\text { Tiquilia } \\
\text { gossypina } \\
\text { (0.000- } \\
\text { 0.821) } \\
\text { Hedeoma } \\
\text { hyssopifolia } \\
\text { (0.000- } \\
\text { 0.821) } \\
\text { Leuciva } \\
\text { dealbata } \\
\text { (0.000- } \\
\text { 0.729) }\end{array}$ & 6 & Fig. 1 (l) 2 \\
\hline $\begin{array}{l}14 . \\
\text { Sonoran - } \\
\text { Chi- } \\
\text { huahuan }\end{array}$ & 24 & $3 \times 2.5$ & $\begin{array}{l}5.20486- \\
5.45486\end{array}$ & 6 & $\begin{array}{l}\text { Thamnosma } \\
\text { texana } \\
\text { (0.813) } \\
\text { Aloisya } \\
\text { wrightii } \\
\text { (0.806) } \\
\text { Acleisanthes } \\
\text { longiflora } \\
\text { (0.806) } \\
\text { Thymophylla } \\
\text { pentachaeta } \\
\text { (1.000) } \\
\text { Acourtia } \\
\text { wrightii } \\
\text { (0.969) } \\
\text { Berberis } \\
\text { haemato- } \\
\text { carpa } \\
\text { (0.813) }\end{array}$ & 1 & Fig. 1 (f) 2 \\
\hline
\end{tabular}




\begin{tabular}{|c|c|c|c|c|c|c|c|}
\hline $\mathrm{AE}$ & $\mathrm{CA}$ & $\begin{array}{l}\text { Cell: } \text { Lat }^{\circ} \mathrm{x} \\
\text { Long }^{\circ}\end{array}$ & $\begin{array}{l}\text { Endemicity } \\
\text { Score (E) }\end{array}$ & End. Ssp. & $\begin{array}{l}\text { Species } \\
\text { Giving Score } \\
\text { (endemicity } \\
\text { score) }\end{array}$ & Ind. AEs & Map \\
\hline $\begin{array}{l}\text { 15. Chi- } \\
\text { huahuan } \\
\text {-(to S } \\
\text { Prairie) }\end{array}$ & 10 & $3 \times 1.5$ & $\begin{array}{l}8.20985- \\
8.11247\end{array}$ & 12 & $\begin{array}{l}\text { Carlowrightia } \\
\text { texana } \\
\text { (0.694- } \\
\text { 0.833) } \\
\text { Asclepias } \\
\text { brachys- } \\
\text { tephana } \\
\text { (0.711- } \\
\text { 0.806) } \\
\text { Asclepias } \\
\text { texana } \\
\text { (0.000- } \\
\text { 0.733) Dalea } \\
\text { pogonathera } \\
\text { (0.000- } \\
\text { 0.789) } \\
\text { Telosiphonia } \\
\text { macrosiphon } \\
\text { (0.000- } \\
\text { 0.767) } \\
\text { Tiquilia } \\
\text { greggi } \\
\text { (0.750- } \\
\text { 0.767) } \\
\text { Guaiacum } \\
\text { angusti- } \\
\text { folium } \\
\text { (0.000- } \\
\text { 0.767) } \\
\text { Cryptantha } \\
\text { mexicana } \\
\text { (0.000-0.706 } \\
\text { ) Jefea } \\
\text { brevifolia } \\
\text { (0.719- } \\
\text { 0.733) } \\
\text { Lygodesmia } \\
\text { texana } \\
\text { (0.000- } \\
\text { 0.711) } \\
\text { Boerhavia } \\
\text { linearifolia } \\
\text { (0.694- } \\
\text { 0.706) } \\
\text { Linum } \\
\text { vernale } \\
\text { (0.000- } \\
\text { 0.700) }\end{array}$ & 4 & Fig. 1 (d) 2 \\
\hline
\end{tabular}




\begin{tabular}{|c|c|c|c|c|c|c|c|}
\hline $\mathrm{AE}$ & $\mathrm{CA}$ & $\begin{array}{l}\text { Cell: } \text { Lat }^{\circ} \mathrm{x} \\
\text { Long }^{\circ}\end{array}$ & $\begin{array}{l}\text { Endemicity } \\
\text { Score (E) }\end{array}$ & End. Ssp. & $\begin{array}{l}\text { Species } \\
\text { Giving Score } \\
\text { (endemicity } \\
\text { score) }\end{array}$ & Ind. AEs & Map \\
\hline $\begin{array}{l}\text { 16. N Chi- } \\
\text { huahuan }\end{array}$ & 14 & $3 \times 1.5$ & $\begin{array}{l}3.18750- \\
3.43750\end{array}$ & 5 & $\begin{array}{l}\text { Cynanchum } \\
\text { pringlei } \\
\text { (0.688- } \\
\text { 1.000) } \\
\text { Tiquillia } \\
\text { gossypina } \\
\text { (0.000- } \\
\text { 1.000) } \\
\text { Acleisanthes } \\
\text { crassifolia } \\
\text { (0.000- } \\
\text { 1.000) } \\
\text { Thymopyilla } \\
\text { micropoides(0. } \\
\text { 0.833) } \\
\text { Funasrum } \\
\text { torrei } \\
\text { (0.000- } \\
\text { 0.833) }\end{array}$ & $\begin{array}{c}3 \\
000- \\
0\end{array}$ & Fig. 1 (e) \\
\hline $\begin{array}{l}\text { 17. SE } \\
\text { Texas }\end{array}$ & 13 & $3 \times 1.5$ & $\begin{array}{l}2.2500- \\
2.5000\end{array}$ & 3 & $\begin{array}{l}\text { Brickellia } \\
\text { dentata } \\
\text { (0.750- } \\
\text { 1.000) Dalea } \\
\text { lasiathera } \\
\text { (0.750- } \\
1.000) \\
\text { Mimosa } \\
\text { latidens } \\
\text { (0.000- } \\
0.813)\end{array}$ & 3 & Fig. $1(\mathrm{k}) 2$ \\
\hline
\end{tabular}




\begin{tabular}{|c|c|c|c|c|c|c|c|}
\hline $\mathrm{AE}$ & CA & $\begin{array}{l}\text { Cell: } \text { Lat }^{\circ} \mathrm{x} \\
\text { Long }^{\circ}\end{array}$ & $\begin{array}{l}\text { Endemicity } \\
\text { Score (E) }\end{array}$ & End. Ssp. & $\begin{array}{l}\text { Species } \\
\text { Giving Score } \\
\text { (endemicity } \\
\text { score) }\end{array}$ & Ind. AEs & Map \\
\hline $\begin{array}{l}\text { 18. S } \\
\text { Texas - } \\
\text { Coahuila }\end{array}$ & 2 & $3 \times 2.5$ & $\begin{array}{l}3.1428- \\
3.50000\end{array}$ & 5 & $\begin{array}{l}\text { Funastrum } \\
\text { torrei } \\
\text { (0.000- } \\
\text { 1.000) } \\
\text { Tiquilia } \\
\text { gossypina } \\
\text { (0.000- } \\
\text { 1.000) } \\
\text { Brickellia } \\
\text { cylindracea } \\
\text { (0.000- } \\
\text { 1.000) } \\
\text { Chamae- } \\
\text { saracha } \\
\text { edwardiana } \\
\text { (0.00-0.833) } \\
\text { Acleisanthes } \\
\text { acutifolia } \\
\text { (0.000- } \\
\text { 1.000) }\end{array}$ & 6 & Fig. 1 (i) 2 \\
\hline $\begin{array}{l}19 . \\
\text { Tamauli- } \\
\text { pan } \\
- \\
\text { Chihuahuan } \\
-\end{array}$ & 19 & $3 \times 2.5$ & $\begin{array}{l}2.54167- \\
2.79167\end{array}$ & 3 & $\begin{array}{l}\text { Cryptantha } \\
\text { mexicana } \\
\text { (0.875) } \\
\text { Viguiera } \\
\text { stenoloba } \\
\text { (0.833) } \\
\text { Boerhavia } \\
\text { linearifolia } \\
\text { (0.833) }\end{array}$ & 1 & Fig. 1 (j)3 \\
\hline
\end{tabular}




\begin{tabular}{|c|c|c|c|c|c|c|c|}
\hline $\mathrm{AE}$ & $\mathrm{CA}$ & $\begin{array}{l}\text { Cell: } \text { Lat }^{\circ} \mathrm{x} \\
\text { Long }^{\circ}\end{array}$ & $\begin{array}{l}\text { Endemicity } \\
\text { Score (E) }\end{array}$ & End. Ssp. & $\begin{array}{l}\text { Species } \\
\text { Giving Score } \\
\text { (endemicity } \\
\text { score) }\end{array}$ & Ind. AEs & Map \\
\hline $\begin{array}{l}\text { 20. Chi- } \\
\text { huahuan } \\
- \\
\text { Tamaulipan } \\
\text {-SME }\end{array}$ & 34 & $3 \times 1.5$ & $\begin{array}{l}9.70358- \\
10.48258\end{array}$ & 11 & $\begin{array}{l}\text { Condalia } \\
\text { ericoides } \\
\text { (0.833) } \\
\text { Peganum } \\
\text { mexicanum } \\
\text { (0.778) He- } \\
\text { liotropium } \\
\text { conferti- } \\
\text { folium } \\
\text { (0.833) } \\
\text { Acleisanthes } \\
\text { obtusa } \\
\text { (0.778) } \\
\text { Asclepias } \\
\text { brachys- } \\
\text { tephana } \\
\text { (0.775) } \\
\text { Cynanchum } \\
\text { barbigerum } \\
\text { (0.750) } \\
\text { Brickellia } \\
\text { laciniata } \\
\text { (0.750) } \\
\text { Vachellia } \\
\text { rigidula } \\
\text { (0.722) } \\
\text { Forestiera } \\
\text { angustifolia } \\
\text { (0.705) } \\
\text { Justicia } \\
\text { pilosella } \\
\text { (0.705) } \\
\text { Psilostrophe } \\
\text { gnaphalodes } \\
\text { (0.700) }\end{array}$ & 1 & Fig. 1 (a) 2 \\
\hline
\end{tabular}




\begin{tabular}{|c|c|c|c|c|c|c|c|}
\hline $\mathrm{AE}$ & $\mathrm{CA}$ & $\begin{array}{l}\text { Cell: } \text { Lat }^{\circ} \mathrm{x} \\
\text { Long }^{\circ}\end{array}$ & $\begin{array}{l}\text { Endemicity } \\
\text { Score (E) }\end{array}$ & End. Ssp. & $\begin{array}{l}\text { Species } \\
\text { Giving Score } \\
\text { (endemicity } \\
\text { score) }\end{array}$ & Ind. AEs & Map \\
\hline $\begin{array}{l}\text { 21. E } \\
\text { Madrean - } \\
\text { Tamauli- } \\
\text { pan }\end{array}$ & 33 & $3 \times 1.5$ & $\begin{array}{l}6.97000- \\
7.04000\end{array}$ & 8 & $\begin{array}{l}\text { Cynanchum } \\
\text { barbigerum } \\
\text { (0.906) } \\
\text { Menodora } \\
\text { heterophyla } \\
\text { (0.781) } \\
\text { Cordia } \\
\text { podocephala } \\
\text { (0.750) He- } \\
\text { liotropium } \\
\text { conferti- } \\
\text { folium } \\
\text { (0.750) } \\
\text { Matelea } \\
\text { reticulata } \\
\text { (0.750) } \\
\text { Justicia } \\
\text { pilosella } \\
\text { (0.725) } \\
\text { Gohnatia } \\
\text { hypoleuca } \\
\text { (0.722) } \\
\text { Mimosa } \\
\text { malacophylla } \\
\text { (0.719) }\end{array}$ & 1 & Fig. 1 (g) 2 \\
\hline
\end{tabular}




\begin{tabular}{|c|c|c|c|c|c|c|c|}
\hline $\mathrm{AE}$ & $\mathrm{CA}$ & $\begin{array}{l}\text { Cell: } \text { Lat }^{\circ} \mathrm{x} \\
\text { Long }^{\circ}\end{array}$ & $\begin{array}{l}\text { Endemicity } \\
\text { Score (E) }\end{array}$ & End. Ssp. & $\begin{array}{l}\text { Species } \\
\text { Giving Score } \\
\text { (endemicity } \\
\text { score) }\end{array}$ & Ind. AEs & Map \\
\hline $\begin{array}{l}\text { 22. SC } \\
\text { USA - E } \\
\text { Madrean }\end{array}$ & 0 & $3 \times 2.5$ & $\begin{array}{l}8.82143- \\
10.0000\end{array}$ & 21 & 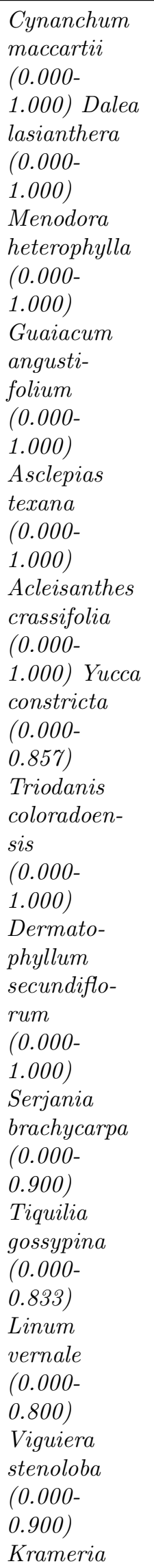 & 16 & Fig. 1 (j) 4 \\
\hline
\end{tabular}




\begin{tabular}{|c|c|c|c|c|c|c|c|}
\hline $\mathrm{AE}$ & $\mathrm{CA}$ & $\begin{array}{l}\text { Cell: } \text { Lat }^{\circ} \mathrm{x} \\
\text { Long }^{\circ}\end{array}$ & $\begin{array}{l}\text { Endemicity } \\
\text { Score (E) }\end{array}$ & End. Ssp. & $\begin{array}{l}\text { Species } \\
\text { Giving Score } \\
\text { (endemicity } \\
\text { score) }\end{array}$ & Ind. AEs & Map \\
\hline $\begin{array}{l}\text { 23. S } \\
\text { Prairie }\end{array}$ & 30 & $3 \times 1.5$ & $\begin{array}{l}3.05711- \\
3.30711\end{array}$ & 4 & $\begin{array}{l}\text { Tetraneuris } \\
\text { scaposa } \\
\text { (0.833) } \\
\text { Asclepias } \\
\text { arenaria } \\
\text { (0.788) } \\
\text { Dalea aurea } \\
\text { (0.731) } \\
\text { Senecio } \\
\text { ridellii } \\
\text { (0.705) }\end{array}$ & 1 & Fig. 2 (a) \\
\hline
\end{tabular}




\begin{tabular}{|c|c|c|c|c|c|c|c|}
\hline $\mathrm{AE}$ & $\mathrm{CA}$ & $\begin{array}{l}\text { Cell: } \text { Lat }^{\circ} \mathrm{x} \\
\text { Long }^{\circ}\end{array}$ & $\begin{array}{l}\text { Endemicity } \\
\text { Score (E) }\end{array}$ & End. Ssp. & $\begin{array}{l}\text { Species } \\
\text { Giving Score } \\
\text { (endemicity } \\
\text { score) }\end{array}$ & Ind. AEs & Map \\
\hline $\begin{array}{l}\text { 24. Co- } \\
\text { manchian }\end{array}$ & 9 & $3 \times 1.5$ & $\begin{array}{l}10.06817- \\
9.938750\end{array}$ & 16 & 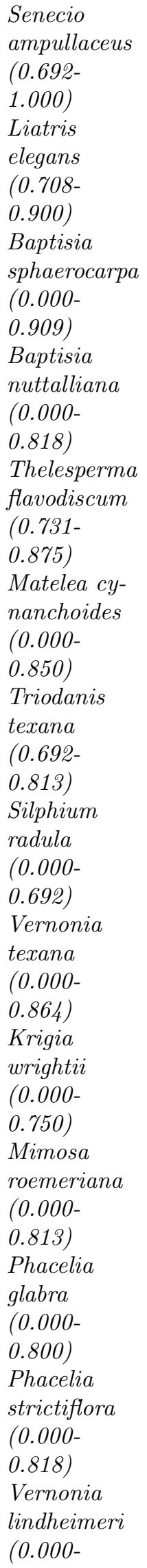 & 6 & Fig. 1 (b) 2 \\
\hline
\end{tabular}




\begin{tabular}{|c|c|c|c|c|c|c|c|}
\hline $\mathrm{AE}$ & $\mathrm{CA}$ & $\begin{array}{l}\text { Cell: } \text { Lat }^{\circ} \mathrm{x} \\
\text { Long }^{\circ}\end{array}$ & $\begin{array}{l}\text { Endemicity } \\
\text { Score (E) }\end{array}$ & End. Ssp. & $\begin{array}{l}\text { Species } \\
\text { Giving Score } \\
\text { (endemicity } \\
\text { score) }\end{array}$ & Ind. AEs & Map \\
\hline $\begin{array}{l}25 . \\
\text { Edwards } \\
\text { Plateau }\end{array}$ & 17 & $3 \times 1.5$ & $\begin{array}{l}1.75000- \\
2.0000\end{array}$ & 2 & $\begin{array}{l}\text { Tradescantia } \\
\text { edwardsiana(0 } \\
1.000) \\
\text { Mimosa } \\
\text { roemeriana } \\
(0.000- \\
1.000)\end{array}$ & $\begin{array}{l}2 \\
900-\end{array}$ & Fig. 1 (c) 2 \\
\hline $\begin{array}{l}\text { 26. Gulf } \\
\text { Coast - } \\
\text { Atlantic }\end{array}$ & 41 & $3 \times 1.5$ & $\begin{array}{l}2.19837- \\
2.44837\end{array}$ & 3 & $\begin{array}{l}\text { Sabatia } \\
\text { brevifolia } \\
\text { (0.773) } \\
\text { Chaptalia } \\
\text { tomentosa } \\
\text { (0.773) } \\
\text { Zigadenus } \\
\text { glaberrimus } \\
\text { (0.692) }\end{array}$ & 1 & Fig. 1 (a) 3 \\
\hline
\end{tabular}

Table 1. Mt-mountains, Gr-Great, Plt-Plateau, Chih-Chihuahua, Tam-Tamaulipas, ComanchComanchian, TX-Texas, S-South, N-North, E-East, W-West, sp-species, lat-latitude, long-longitude.

Fig. 1 Legend

(a1 ). AE1. Mid Rocky; (a2 ). AE20. Chih; (a3 ). AE26. Gulf; (b1 ). AE6. Moh-Son; (b2 ). AE24. Comanche; (c1 ). AE11.Col Plt-Moh-Col Des; (c2 ). AE25. Edw Plt; (d1 ). AE4. Gr Bas-Moh; (d2 ). AE15. Chih (S Prair); (e ). AE16. N Chih-S TX; (f1 ). AE3. S Rocky-Col Plt-E Madr; (f2 ). AE14. Son-Chih; (g1 ). AE7. S Gr Bas-Moh-N Son; (g2 ). AE21. E Madr-Tam; (h ). AE12. Madr Reg Mont; (i1 ). AE10. Col Plt; (i2 ). AE18. S TX-Coah; (j1 ). AE5. S CFP-SE Gr Bas-Moh-N Son; (j2 ). AE9. SW N Am; (j3 ). AE 19. Chih-Tam; (j4 ). AE 22. SC USA-E Madr; (k1 ). AE2. E Gr Bas-Rocky; (11 ). AE8. S Sier Nev-Moh; (12 ). AE 13. Apach-N Chih

Abreviations: Chih - Chihuahuan; Moh - Mohave; Son - Sonoran; Co l- Colorado; Plt - Plateau; Des - Desert; Edw - Edwards; Gr Bas - Great Basin; Prair - Prairie; TX - Texas; Madr - Madrean Reg - Region; Mont - Montane; Coah - Coahuila; CFP - California Floristic Province; Am - American;Tam - Tamaulipan; Sier Nev - Sierra Nevada; Apach - Apachian

Fig. 2 Legend

(a). AE9. SW N Am; (b). AE23. S Prairie

Appendix 1. Texas map.

Appendix 2. Table S1.

Appendix 3. List of species with authorities used in the analyses. 

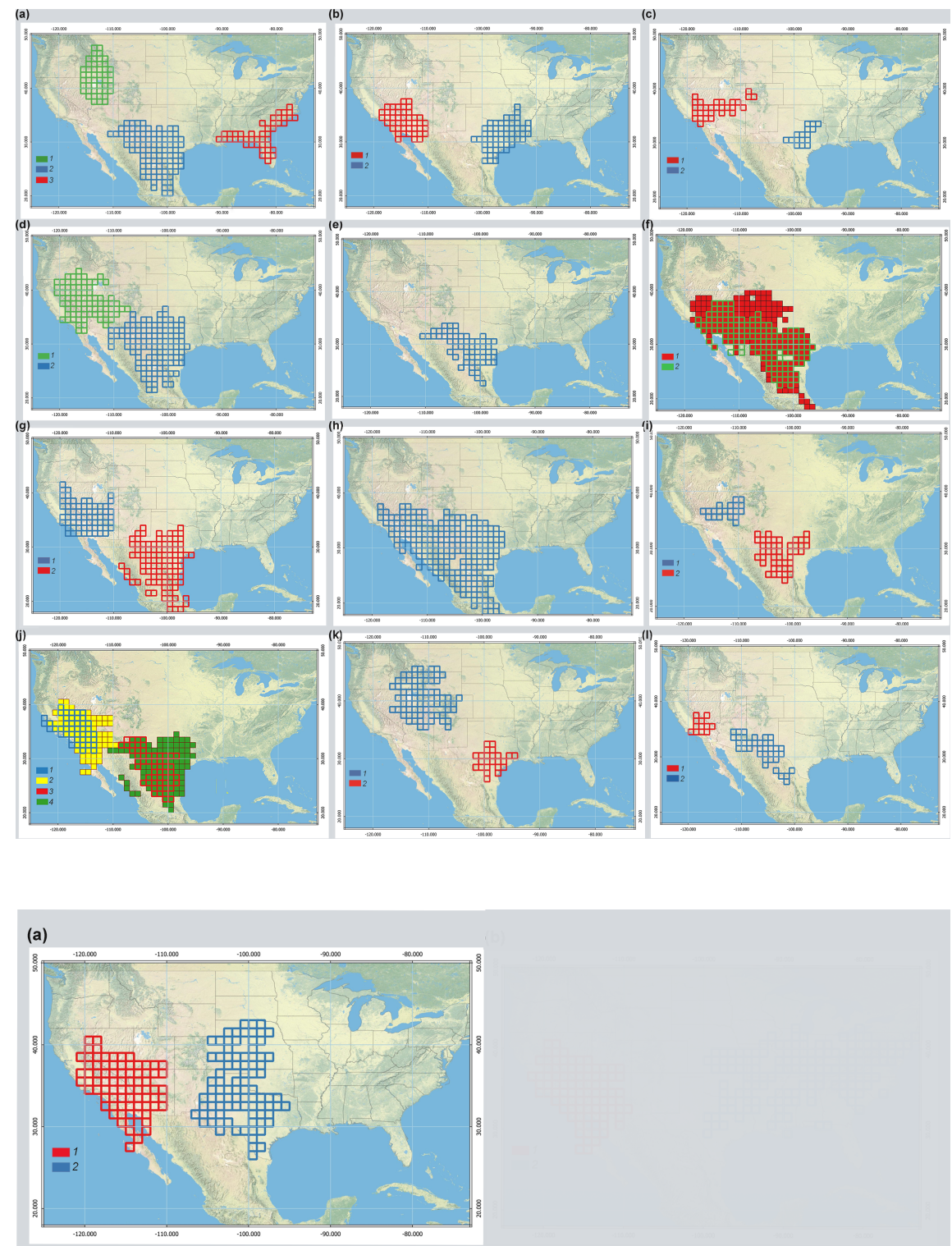